\title{
Regional Trade Integration by Environmental Goods
}

\author{
Atsuko Matsumura \\ Tokyo International University, Saitama, Japan
}

\begin{abstract}
With the emphasis on the effects of regional trade integration and production fragmentation, this paper investigates the determinants of trade networks focusing on environmental goods, according to the Asia-Pacific Economic Cooperation classification by each of the commodity groups of HS84, HS85, and HS90, which include important commodities having the purpose of protecting the environments. The gravity analysis with consideration of trade in parts and components, for which newly industrialized Asian economies have advantage, and regional dummies verifies not only that trade in environmental goods is expanding more rapidly but also production fragmentation depending on trade in parts and components is a key factor to expand the overall trade in environmental goods among the APEC countries and members of the Japan-Association of Southeast Asian Nations Free Trade Agreements. These results suggest that the commitment by Asia-Pacific Economic Cooperation to liberalize trade of environmental goods is crucial for regional economic integration through promoting international
\end{abstract}

\footnotetext{
* Corresponding Author: Atsuko Matsumura; Faculty of Economics, Tokyo International University, 1-13-1 Kasumigaseki, Kawagoe-City, Saitama 350-1197, Japan; Tel: +81 492321111, Fax: +81 492321119, E-mail:atsukom@ tiu.ac.jp.
}

\footnotetext{
Acknowledgements: This research is funded by Grants-in-Aid Scientific Research(C), Japan Society for Promoting Science, as research with no.25380319. This is a revised version of a paper presented at the 73rd meeting of the Japan Society of International Economics at Kyoto Sangyo University, 26 October 2014. The author would like to acknowledge the discussant and the other participants of the meeting for their valuable comments. The author would like to acknowledge anonymous referees for valuable comments.
} 
production fragmentation and also for environmental protection by expanding world demand for environmental goods through activating regional trade.

JEL Classifications: F13, F14, F15, F18

Keywords: Environmental Goods, Asia-Pacific Economic Cooperation (APEC), JapanAssociation of Southeast Asian Nations Free Trade Agreement (Japan-ASEAN FTA), Gravity Model, Production Fragmentation

\section{Introduction}

The importance of trade liberalization in environmental goods has been discussed since the end of the Uruguay Round in the World Trade Organization (WTO). The Doha Ministerial Declaration in 2001 considers the reduction or elimination of tariff and nontariff barriers to trade in environmental goods and services in order to pursue win-win results for trade, development, and the environment. Members of the WTO have been working to liberalize trade in goods and services that can benefit the natural environment, and these talks take place in Special Sessions of the Trade and Environment Committee of the WTO.

There exists a list of environmental goods in the WTO based on Harmonized System (HS) -6 lines submitted by WTO members. It contains the reference universe of over 500 environmental goods of interest to member countries. On the other hand, in 2012, AsiaPacific Economic Cooperation (APEC) put together a list of 54 environmental goods and affirmed their commitment to reduce applied tariff rates to five percent or less on these environmental goods by the end of 2015. Recently, on 8 July 2014 at the WTO, 14 members of WTO launched plurilateral negotiations of the trade liberalization for Environmental Goods. What is important is that their talks will build on the APEC list of 54 environmental goods.

With the exception of a good belonging to HS44, the environmental goods in the agreed list of APEC are those goods that come under headings of HS84 (general machinery), HS85 (electric machinery), and HS90 (precision machinery), in which many developed countries seem to have comparative advantage. Recently, however, the newly industrialized countries seem to have become producers of some kinds of 
these environmental goods. It is well known that international production fragmentation is an important feature of the world economy, especially for machinery industries in East Asia, by exchanging parts and components within the region ${ }^{1}$. In this sense, trade of environmental goods is worth investigated vigorously, from the perspective of production fragmentation and regional aspects, to find out the elements for spreading the production and trade of these goods. The environmental goods are especially selected for the object of this study, with the perception that the proliferation of every kind of environmental goods through international trade is indispensable for environmental protection in the modern world.

This paper examines the structure of the trade networks of environmental goods put together by APEC, focusing on the effects of regional blocs and production fragmentation. The main contribution of this paper is to investigate the determinants of trade focusing on environmental goods, according to the APEC classification by each of the commodity groups of HS84, HS85, and HS90, which include important commodities leading the world trade and having the peculiar purposes of protecting the environment. The analytical framework is based on the gravity model with consideration of production fragmentation on a regional basis.

The paper is organized as follows. Section II clarifies the hypotheses to be investigated in this analysis, Section III provides the APEC list of environmental goods that are the subject of the analysis and the structure of comparative advantage in the main countries of the study. It also clarifies the relevance of the comparative advantage structure to production fragmentation in the ASEAN 5 countries. Section IV shows the analytical model and estimating equations. Section $\mathrm{V}$ investigates the estimation results of both cross-section analysis and panel analysis to verify the hypotheses. In Section VI, the conclusion of this paper is presented.

\section{Hypotheses}

Two hypotheses are proposed regarding the regional effect and the production fragmentation effect for the trade of environmental goods. Paying attention to the APEC

${ }^{1}$ Kimura(2013), Kimura et al (2007), and Athukorala(2006). 
group, where trade liberalization of environmental goods is promoted, and JapanASEAN free trade area, where manufacturing trade has increased very quickly mainly by establishing production and distribution networks, the first hypothesis is that the trade of environmental goods is accelerated within those regions.

There are reasons why the trade in environmental goods is expected to expand rapidly in APEC countries and the members of Japan-Association of Southeast Asian Nations Free Trade Agreement (Japan-ASEAN FTA). Firstly, APEC countries have been eager to liberalize trade of environmental goods by taking trade-enhancing solutions to address global environmental challenges since the Honolulu agreement of 2011, as described in the previous section, the Leaders' Declaration of 2012 indicates that member countries endorsed of the APEC List of Environmental Goods and affirmed the members' commitment to reduce the applied tariff rates to $5 \%$ or less on these environmental goods by the end of 2015, taking into account the countries' economic circumstances. Secondly, the Leaders' Declaration of 2012 also indicates that the member countries affirmed their commitment to achieving an APEC-wide target of 10\% improvement in supply-chain performance by 2015, in terms of reduction of time, cost, and uncertainty of moving goods and services through the Asian-Pacific region taking into consideration individual economy's circumstances. In this way, the Declaration of 2012 admits that the reliability of supply chains is crucial to facilitate trade, maintain sustainable development, and environmental security by increasing trade in APEC region. ${ }^{2}$ Consequently, APEC is making efforts to foster trade of environmental goods by tariff reductions for the member countries to access important environmental technologies for environmental protection, and also to increase production of environmental goods by deploying the useful supply chains in the international production networks.

On the other hand, focusing on East Asian countries including Japan, since the 1990s the formation of the production fragmentation networks in machinery industries with back-and-forth transactions among the member countries has been accompanied by the weight shift of the trade pattern from machinery final goods to machinery parts and components, as clarified in several researches. ${ }^{3}$ As the environmental goods of this study are made of the machineries of HS84, HS85, and HS90, the East-Asian countries are considered to have the comparative advantage in some of the environmental machinery goods as shown in Section III. This paper focuses on the countries of Japan-ASEAN

\footnotetext{
APEC (2012) for details.

Ando and Kimura (2010).
} 
FTA including Japan and five starting member countries and Vietnam among East-Asian countries, because this FTA came into effect on December 1, 2008, one year before the target years of this study, and it is worth investigating the effect of this FTA for comparing with that of APEC.

The second hypothesis is that the international production fragmentation has the driving force of trade increase in environmental goods through increased trade of parts and components. Trade volume is expected to increase by international production fragmentation because of the proliferation of complex supply chains by the producers pursuing production efficiency. Practically, as international production fragmentation affects production processes to divide into many fragments across country borders, trade of parts and components must be activated. Also, international production fragmentation makes it possible for the parts and components to be produced in the most efficient country, and this concentration of production accelerates trade by the cost decline under increasing returns to scale production.

In order to examine the effect of international production fragmentation on trade, many studies emphasize the importance of taking into account the trade share of intermediate goods. For example, the study of Baldwin and Taglioni (2011) includes the ratio of intermediates to total trade in the standard gravity equation as an explanatory variable and finds that bilateral trade-links marked by a high share of intermediates tend to have too much trade compared to the prediction of the standard gravity equation. The study of fragmentation trade of Athukolara (2006) is based on a systematic separation of trade in parts and components from total trade flows. Jones et al. (2005) point out that the consequences of production fragmentation manifest itself in a rapid expansion of international trade in parts and components and conduct the analysis of determinants of trade in parts and components on a regional or global basis. According to those researches, in this analysis, the share of parts and components is included as the proxy of the degree of production fragmentation.

The analysis is conducted using the gravity model which serves to make clear the determinants of the trade networks among the 43 countries including APEC countries, European countries, and the newly industrialized countries ${ }^{4}$. The estimation is conducted by each of the environmental commodity groups, HS84, HS85, and HS90 which have different characteristics, for convenience of verifying the hypotheses.

\footnotetext{
${ }^{4}$ The selected countries are indicated in Section IV.
} 


\section{APEC List of Environmental Goods}

\section{A. Characteristics of the APEC list}

The APEC list of environmental goods is composed of 54 items in the 6-digit code of the HS system, with the exception of HS441872. All 53 items belong to general machinery (HS84), electric machinery (HS85), or precision machinery (HS90). ${ }^{5} 23$ items belong to HS84, of which 9 items are the parts and components; 11 items belong to HS85, of which 4 items are the parts and components; and 19 items belong to HS90, of which 6 items are the parts and components. The categories about environmental protection for those goods are waste management and water treatment, air pollution control, carbon capture and storage, renewable energy, and environmental monitoring analysis and assessment equipment.

If we compare this APEC list of environmental goods with the list prepared by the Committee on Trade and Environment Special Session in the WTO according to WTO members' submissions of environmental goods of interest, all goods in the APEC list except 441872, 901380, and 901390 are included in the WTO list. It is clear that the two lists contain goods from the various points of view for environmental protection.

If we check the nature of high technology in each good using the ratio of Research and Development (R\&D) expenditure in sales calculated by Eurostat (1996), 15 goods are defined as high-tech over 19 goods in the group of HS90. ${ }^{6}$ In the HS90 group, HS901390, HS903149, HS903180, and HS903190 are not included in the group of hightech goods, but the last three goods can be considered as high-tech goods because of the WTO list. Therefore all the goods related to Environmental Monitoring Analyzing Equipment of HS90 in the APEC list are considered as goods concerning environmental technology.

\footnotetext{
${ }^{5}$ Environmental Goods in APEC list are as follows: 441872, 840290, 840410, 840420, 840490, 840690, 841182, 841199, $841290,841780,841790,841919,841939,841960,841989,841990,842121,842129,842139,842199,847420,847982,847989$, $847990,850164,850231,850239,850300,850490,851410,851420,851430,851490,854140,854390,901380,901390,901580$, 902610, 902620, 902680, 902690, 902710, 902720, 902730, 902750, 902780, 902790, 903149, 903180, 903190, 903289, 903290, 903300. (the version of HS 2012)

${ }^{6}$ High-tech goods are defined by Ishida (2011) using the calculation of Eurostat (1996).
} 


\section{B. Structure of comparative advantage}

We start to clarify the structure of comparative advantage of each environmental good in the main countries. The simple index of Revealed Comparative Advantage (RCA) is defined by Balassa (1965).

$$
\left(X_{i j} / X_{t j}\right) /\left(X_{i w} / X_{t w}\right)
$$

Here, $X_{i j}$ is export of good $i$ from country $j, X_{t j}$ is total export from country $j, X_{i w}$ is world export of good $i$, and $X_{t w}$ is world total exports. Data of exports from the APEC countries except for Papua New Guinea, Peru, and Russia and European Union (EU) 28 countries are used. The RCA index, thus, contains a comparison of export structure of country $j$, the numerator, with the world export structure which is the denominator. When RCA equals 1 for a given good in a given country, the percentage share of that sector is identical with that of the world. If RCA is above 1, the country is regarded as having comparative advantage so that this country specializes in that sector. Also if RCA is below 1 , the good is regarded as having comparative disadvantage in that country.

According to the calculation results of RCA for 19 main countries in Asia and Europe, Figure 1 shows the number of goods with RCA exceeding 1 in each country, in each of the three groups of HS84, HS85, and HS90. In a total of three groups, Germany, United States (US), Japan, and Italy have extremely large numbers of RCA exceeding 1, with 40, 35, 32, and 29 respectively. The second group of countries with a relatively big number includes Singapore with 19, United Kingdom (UK) with 17, France and South Korea with 16, China with 12, Spain with 11, and Hong Kong with 10. If we focus on the numbers for each commodity group, Italy has 21 goods, Germany has 18, US has 13, Japan has 12, Korea has 10, China has 8, Spain has 7, France has 6, and both Singapore and Indonesia have 5 for the group of HS84. In the group of HS85, both Germany and Japan have 8 goods, and both US and Italy have 6 goods. In the group of HS90 which has a high share of high-tech goods, US has 16, Germany has 14, Japan has 12, UK has 11, Singapore has 10, and France has 9 goods. 
Figure 1. Number of goods with RCA exceeding 1 by HS group (2013)

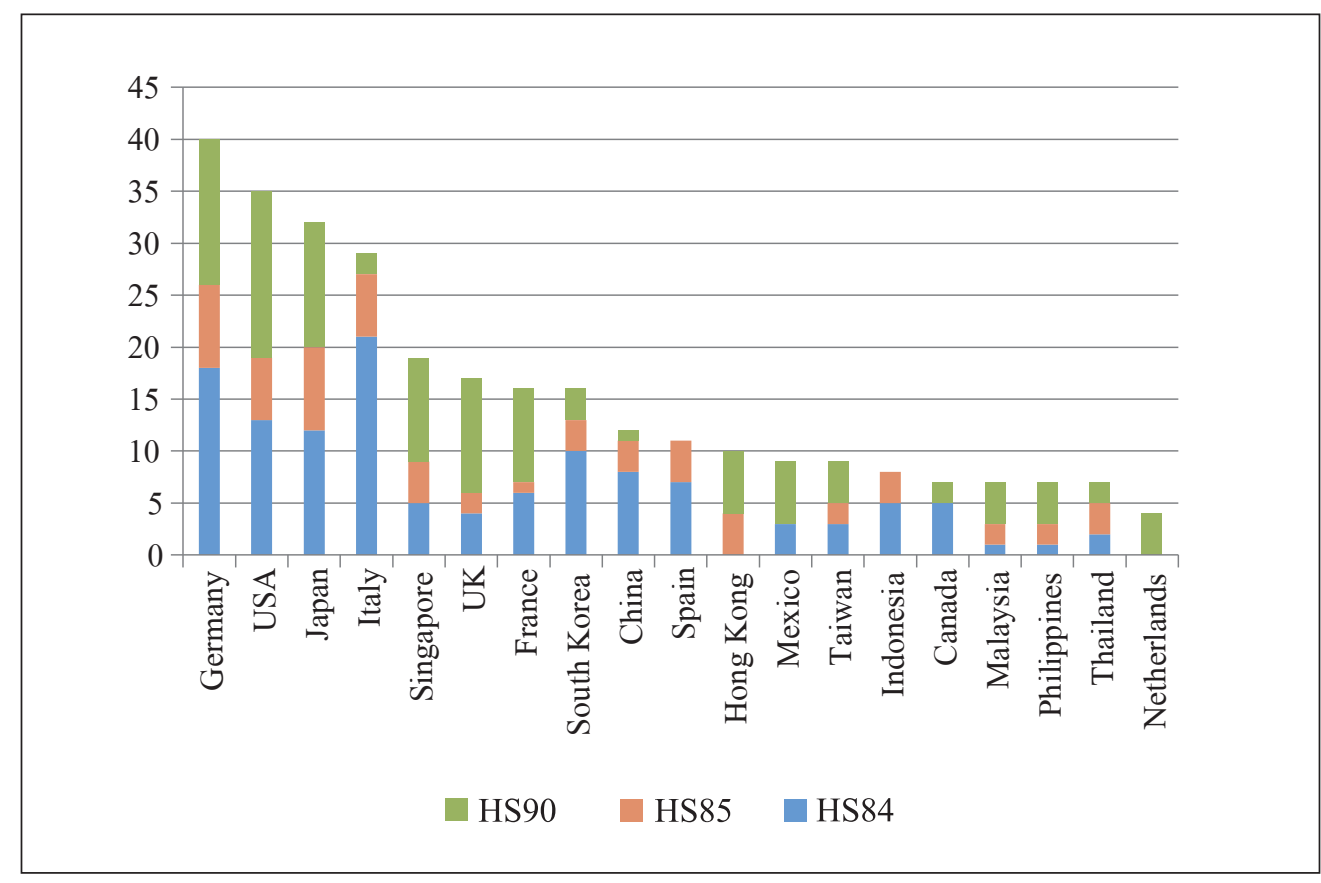

(Source) Author's calculation using data available from Global Trade Atlas.

Turning to ASEAN 5 countries, with the exception of Singapore which has more goods with comparative advantage, Thailand, Malaysia, Indonesia, and Philippines have 7 or 8 goods with RCA exceeding 1 in total, and those goods with their comparative advantage are found to be parts and components or final goods attached to the comparative advantage for their parts and components. Those facts are shown in Table 1 , where it is shown that most goods with RCA exceeding 1 for ASEAN 5 are parts and components or final goods together with the comparative advantage for their parts and components, suggesting the formation of international production fragmentation networks in this region. The exceptional five goods are HS841939 and HS847420 for Indonesia, HS850239 for Singapore, Thailand, and Indonesia, HS854140 for Singapore, Malaysia, and Philippines, and HS901580 for Singapore and Malaysia. 
Table 1. RCA in ASEAN 5 and the importance of parts and component

\begin{tabular}{|c|c|c|c|c|c|c|}
\hline HS Codes & Parts or not & Singapore & Thailand & Malaysia & Indonesia & Philippines \\
\hline 840290 & Parts & & & & & \\
\hline \multicolumn{7}{|l|}{840410} \\
\hline 840420 & & & & & 7.69 & \\
\hline 840490 & Parts & 1.78 & & & 2.49 & \\
\hline 840690 & Parts & & & & 1.06 & \\
\hline 841182 & & 1.23 & & & & \\
\hline 841199 & Parts & 1.13 & & & & \\
\hline 841290 & Parts & 2.39 & & & & \\
\hline \multicolumn{7}{|l|}{841780} \\
\hline 841790 & Parts & & & & & \\
\hline \multicolumn{7}{|l|}{841919} \\
\hline 841939 & & & & & 1.32 & \\
\hline \multicolumn{7}{|l|}{841960} \\
\hline \multicolumn{7}{|l|}{841989} \\
\hline 841990 & Parts & & & & & \\
\hline \multicolumn{7}{|l|}{842121} \\
\hline \multicolumn{7}{|l|}{842129} \\
\hline 842139 & & & 1.18 & & & \\
\hline 842199 & Parts & & 1.5 & & & \\
\hline 847420 & & & & & 1.04 & \\
\hline \multicolumn{7}{|l|}{847982} \\
\hline \multicolumn{7}{|l|}{847989} \\
\hline 847990 & Parts & 3.3 & & 1.33 & & 10.20 \\
\hline \multicolumn{7}{|l|}{850164} \\
\hline \multicolumn{7}{|l|}{850231} \\
\hline 850239 & & 1.09 & 1.48 & & 1.41 & \\
\hline 850300 & Parts & & & & & \\
\hline 850490 & Parts & & & & & 3.04 \\
\hline \multicolumn{7}{|l|}{851410} \\
\hline 851420 & & & 1.03 & & & \\
\hline 851430 & & & & & 5.84 & \\
\hline
\end{tabular}




\begin{tabular}{|c|c|c|c|c|c|c|}
\hline HS Codes & Parts or not & Singapore & Thailand & Malaysia & Indonesia & Philippines \\
\hline 851490 & Parts & 1.01 & & & 2.13 & \\
\hline 854140 & & 1.03 & & 3.94 & & 5.35 \\
\hline 854390 & Parts & 7.74 & 4.71 & 1.2 & & \\
\hline \multicolumn{7}{|l|}{901380} \\
\hline 901390 & Parts & & 1.72 & & & \\
\hline 901580 & & 2.69 & & 1.98 & & \\
\hline \multicolumn{7}{|l|}{902610} \\
\hline 902620 & & 1.41 & & 2.44 & & \\
\hline \multicolumn{7}{|l|}{902680} \\
\hline 902690 & Parts & 1.27 & & & & 1.56 \\
\hline \multicolumn{7}{|l|}{902710} \\
\hline 902720 & & 3.61 & & & & \\
\hline 902730 & & 2.41 & & & & \\
\hline 902750 & & 2.22 & & & & \\
\hline 902780 & & 2.05 & & & & \\
\hline 902790 & Parts & 2.49 & & & & \\
\hline \multicolumn{7}{|l|}{903149} \\
\hline 903180 & & & & & & 1.94 \\
\hline 903190 & Parts & 1.57 & & 2.29 & & 1.64 \\
\hline \multicolumn{7}{|l|}{903289} \\
\hline 903290 & Parts & & & 3.63 & & 1.81 \\
\hline 903300 & Parts & 4.08 & 4.65 & & & \\
\hline
\end{tabular}

(Source) Author's calculation using data available from Global Trade Atlas.

\section{Empirical Framework}

The previous section demonstrated the possibility of the formation of international production networks in five ASEAN countries by the biased comparative advantage to parts and components in those countries. This section clarifies the empirical framework using the gravity equation to examine the determinants of trade networks 
for environmental goods. The gravity model is used in numerous studies investigating bilateral trade because the estimation results usually provide an excellent empirical fit. The gravity model specification of this study is made clear by introducing additional explanatory variables to the basic gravity model, focusing on regional effects and product fragmentation effects.

\section{A. Gravity model}

In the early gravity equation, bilateral trade flows are assumed as a function of the product of their GDPs and the distance between them, as shown in the original work of Tinbergen (1962) and other early works of Poyhonen (1963) and Linnemann (1966).

More recent literature, such as Anderson and van Wincoop (2003) and Feenstra (2004), has modified theoretical foundations of the gravity model to account for omitted variable bias related to the exclusion of multilateral resistance terms. To estimate the gravity equation using ordinary least squares, Feenstra (2004) has proposed a solution to control the unobserved multilateral resistance terms by estimating them as countryspecific fixed effects.

Because this study examines the impact of international production fragmentation on trade flows through parts and components trade, the gravity model of final goods based on Constant Elasticity of Substitution (CES) utility function is not suited to this analysis. Baldwin and Taglioni (2011) extend the gravity model to allow for intermediate goods, parts, and components trade among firms, and find theoretically that the perfect solution would require data on total costs to construct the demand shifter for proxy for intermediate imports. Also using the ratio of intermediates to total trade as a regressor in the standard gravity equation, they find that bilateral trade-links marked by a high share of intermediates where production fragmentation arrangements are an important tend to have too much trade compared to the prediction of the standard gravity equation. They suggest that distance is more important for bilateral trade flows dominated by intermediates, reflecting the fact that most production fragmentation arrangements are regional and components trade is more regionalized than overall trade.

As this study considers the importance of production fragmentation for the increase of overall trade, the ratio of intermediates to total trade is introduced as an explanatory variable of the gravity equation. Also, for the variables to take into account the regional effect, regional dummy variables are introduced in the standard gravity model. 


\section{B. Model specification}

To investigate the determinants of trade among the 53 environmental goods in the APEC list focusing on the effects of production fragmentation and regional effects, an analysis is conducted using the gravity model with the following peculiarities. First, analysis of the 53 environmental goods of the APEC list is conducted in each group of HS84, HS85, and HS90 so that different characteristics of the trade flow of each group are made clear, reflecting the difference of technological intensity and the trade share of parts and components in total trade. Second, regional effects are examined for APEC, the EU, and North American Free Trade Agreement (NAFTA). In addition to these regions, the importance of trade networks among the countries of the ASEAN and Japan through the Japan-ASEAN FTA is examined to identify the effect of trade creation in the regional agreement of the so-called ASEAN plus one.

Third, in order to focus on the basis of these regional effects, the magnification effect of trade in parts and components on the growth of intra-regional trade through production fragmentation is examined. In order to examine the fragmentation effect, the ratio of intermediates to overall trade is used in the gravity model, with positive sign expected, because wherever a network of international production fragmentation is created the overall trade together with trade in parts and components is expected to grow faster than in the regions without it. Since Japan has a strong comparative advantage in many environmental goods as we have seen in the previous section, the importance of international supply chains through production fragmentation networks with ASEAN countries on its production structure should become clear. The effect of trade in parts and components on the magnification of overall trade is examined for other regions such as EU and NAFTA.

The fourth characteristic of the study is the introduction of a time effect. Four years of data from 2009 to 2012 are used to conduct cross-section analysis using the data of each year and panel analysis with pooled data. By comparing the results of four crosssection analyses, an evolution of trade in environmental goods can be clarified, and by panel analysis with the inclusion of four years' pooled data the robust characteristics of each commodity group can be shown. The fifth goal of the study is to examine the evolution of time fixed effects such as distance, adjacency, and common language between the pair countries during the four years. By introducing the effect of common language, the trade cost resulting from the cultural or institutional barriers could be estimated to a certain extent, which can be thought to be especially important for trade 
contracts of environmental goods when a network is important to facilitate the search for suitable trade partners for the differentiated products.

The estimating equations for the cross-section analysis for each year are shown in Equations (2) and Equation (3).

$$
\begin{aligned}
\ln \left(T_{i j t}\right)=\alpha & +\beta_{1} \ln \left(G D P_{i t} * G D P_{j t}\right)+\beta_{2} \ln \left(G D P P C_{i t} * G D P P C_{j t}\right)+\beta_{3} \ln \left(D_{i s t_{i j}}\right) \\
& +\beta_{4}\left(A D J_{i j}\right)+\beta_{5}\left(D C L_{i j}\right)+\gamma_{1}(D A P E C)+\gamma_{2}(D E U R)+\gamma_{3}(D N A F T A) \\
& +\gamma_{4}(D J A S N)+\gamma_{5}\left(R P_{i j t}\right)+\varepsilon_{i j t} \\
\ln \left(T_{i j t}\right)=\alpha & +\beta_{1}{ }^{\prime} \ln \left(G D P_{i t} * G D P_{j t}\right)+\beta_{2}{ }^{\prime} \ln \left(G D P P C_{i t} * G D P P C_{j t}\right)+\beta_{3}{ }^{\prime} \ln \left(D i s t_{i j}\right) \\
& +\beta_{4}{ }^{\prime}\left(A D J_{i j}\right)+\beta_{5}{ }^{\prime}\left(D C L_{i j}\right)+\gamma_{1}{ }^{\prime}\left(D A P E C * R P_{i j t}\right)+\gamma_{2}{ }^{\prime}\left(D E U R * R P_{i j t}\right) \\
& +\gamma_{3}{ }^{\prime}\left(D N A F T A * R P_{i j t}\right)+\gamma_{4}{ }^{\prime}\left(D J A S N * R P_{i j t}\right)+\varepsilon_{i j t}
\end{aligned}
$$

The expected signs are:

$$
\begin{gathered}
\beta_{1}>0, \beta_{2}>0, \beta_{3}<0, \beta_{4}>0, \beta_{5}>0, \beta_{1}{ }^{\prime}>0, \beta_{2}{ }^{\prime}>0, \beta_{3}{ }^{\prime}<0, \beta_{4}{ }^{\prime}>0, \beta_{5}{ }^{\prime}>0, \\
\gamma_{1}>0, \gamma_{2}>0, \gamma_{3}>0, \gamma_{4}>0, \gamma_{5}>0, \gamma_{1}^{\prime}>0, \gamma_{2}^{\prime}>0, \gamma_{3}{ }^{\prime}>0, \gamma_{4}^{\prime}>0
\end{gathered}
$$

$T_{i j t}$ stands for the total trade value between country $i$ and country $j$ in year $t$, $\left(G D P_{i t}{ }^{*} G D P P_{j t}\right)$ is GDP product of the two countries, $\left(G D P P C_{i t}{ }^{*} G D P P C_{j t}\right)$ is the product of GDP per capita of the two countries, $\left(D I S T_{i j}\right)$ denotes the distance between capitals of the two countries, $\left(A D J_{i j}\right)$ is a dummy variable for adjacency of the pair countries with 1 if the pair countries have a common border and 0 otherwise, $\left(D C L_{i j}\right)$ is a dummy variable with 1 if the pair countries have a common official language and 0 otherwise. DAPEC, DEUR, DNAFTA, and DJASN are four dummy variables standing for APEC, 15 EU countries until the fourth enlargement in 1995, NAFTA, and Japan-ASEAN FTA, respectively. These variables are used to test the effects of membership in a common regional grouping. For ASEAN countries, Indonesia, Malaysia, Philippines, Thailand, and Singapore (the ASEAN 5) and Vietnam are included. The dummy variable is 1 if both countries are members of the region or regional trade agreement and 0 otherwise. $\left(R P_{i j t}\right)$ stands for the ratio of trade in parts and components in each group of HS84, HS85, and HS90. 
The expected signs are shown below the equations, with positive sign for all the variables except for the distance. The expected sign for the product of Gross Domestic Product (GDP) per capita is positive, indicating that if the pair countries become more developed they tend to specialize more in the environmental goods and to trade them more. ${ }^{7}$ All variables except the dummy variables are logged. In Equation (3), instead of using the ratio of parts and components trade to total trade and regional dummy variables separately, the product of this ratio and each regional dummy variable is used to test the effects of the production fragmentation in intra-regional trade.

For panel analysis with pooled data from 2009 to 2012, panel Ordinary Least Squares (OLS) and a Cross- Section Random Effect Model are conducted because of the time invariant distance data. Here, the error term in Equation (2) and Equation (3) is decomposed to idiosyncratic random, eijt, and cross-section random, uij.

Table 2 lists the 43 sample countries. The study includes European countries, newly developed countries such as India, Brazil, South Africa, and Turkey, and the countries in the APEC group except for Peru, Russia, and Papua New Guinea, 
Table 2. List of $\mathbf{4 3}$ sample countries

\begin{tabular}{|c|c|c|}
\hline APEC & $\mathbf{E U}$ & Other countries \\
\hline Australia & Austria & Brazil \\
\hline Canada & Belgium & Indaia \\
\hline Chile & Bulgaria & South Africa \\
\hline China & Croatia & Switzerland \\
\hline Hong Kong & Czech Republic & Turkey \\
\hline Indonesia & Denmark & \\
\hline Japan & Estonia & \\
\hline Korea & Finland & \\
\hline Malaysia & France & \\
\hline Mexico & Germany & \\
\hline New Zealand & Greece & \\
\hline Philippines & Hungary & \\
\hline Singapore & Ireland & \\
\hline Taiwan & Italy & \\
\hline Thailand & Netherlands & \\
\hline USA & Poland & \\
\hline \multirow[t]{5}{*}{ Vietnam } & Portugal & \\
\hline & Romania & \\
\hline & Spain & \\
\hline & Sweden & \\
\hline & Uk & \\
\hline
\end{tabular}

The data used for the bilateral trade flows are taken from the Global Trade Atlas online data, providing customs trade data by the government of each country. GDP in 1,000 US dollars and GDP per capita in US dollars are from the World Bank's World Development Indicators. Bilateral distances between capitals of the pair countries in kilometers, adjacency, and common language are from the Centre d'Etude Prospectives 
d'Informations Internationales (CEPII) database. Data of GDP and GDP per capita for Taiwan are from the JETRO database originally from the Directorate-General of Budget, Accounting and Statistics, Executive Yuan R.O.C. (Taiwan). The zeros of the trade data are excluded in the analysis.

A summary of descriptive statistics of the variables of total trade value and ratio of parts and components to total trade is given in Table 3, and those of GDP, GDP per capita, and distance are given in Table 4.

Table 3. Summary for trade and trade ratio of parts

\begin{tabular}{|l|c|c|c|c|c|c|c|c|}
\hline HS84 & \multicolumn{4}{|c|}{$\ln \left(\boldsymbol{T}_{i j}\right)($ Total Trade Value $)$} & \multicolumn{3}{c|}{$\boldsymbol{R P}_{i j}$ (Ratio of Parts and Components) } \\
\hline Year & 2009 & 2010 & 2011 & 2012 & 2009 & 2010 & 2011 & 2012 \\
\hline Mean & 9.421 & 9.406 & 9.129 & 9.710 & 0.469 & 0.445 & 0.454 & 0.437 \\
\hline Median & 9.766 & 9.707 & 9.430 & 9.968 & 0.447 & 0.428 & 0.429 & 0.415 \\
\hline Maximum & 15.353 & 15.457 & 15.786 & 15.687 & 1.000 & 1.000 & 1.000 & 1.000 \\
\hline Minimum & 0.000 & 0.000 & 0.000 & 0.000 & 0.000 & 0.000 & 0.000 & 0.000 \\
\hline Standard Deviation & 2.678 & 2.674 & 2.814 & 2.577 & 0.253 & 0.245 & 0.246 & 0.237 \\
\hline Observations & 887 & 893 & 871 & 892 & 887 & 893 & 887 & 892 \\
\hline
\end{tabular}

\begin{tabular}{|l|c|c|c|c|c|c|c|c|}
\hline HS85 & \multicolumn{4}{|c|}{$\ln \left(\boldsymbol{T}_{i j}\right)($ Total Trade Value $)$} & \multicolumn{3}{c|}{$\boldsymbol{R P}_{i j}$ (Ratio of Parts and Components) } \\
\hline Year & 2009 & 2010 & 2011 & 2012 & 2009 & 2010 & 2011 & 2012 \\
\hline Mean & 8.6464 & 8.990 & 9.129 & 9.146 & 0.606 & 0.556 & 0.550 & 0.546 \\
\hline Median & 9.029 & 9.270 & 9.430 & 9.367 & 0.658 & 0.596 & 0.573 & 0.575 \\
\hline Maximum & 15.412 & 16.892 & 15.786 & 15.338 & 1.000 & 1.000 & 1.000 & 1.000 \\
\hline Minimum & 0.000 & 0.000 & 0.000 & 0.000 & 0.012 & 0.000 & 0.000 & 0.000 \\
\hline Standard Deviation & 2.910 & 2.900 & 2.814 & 2.689 & 0.319 & 0.341 & 0.335 & 0.323 \\
\hline Observations & 850 & 874 & 871 & 858 & 850 & 874 & 871 & 858 \\
\hline
\end{tabular}

\begin{tabular}{|l|c|c|c|c|c|c|c|c|}
\hline HS90 & \multicolumn{3}{|c|}{$\ln \left(\boldsymbol{T}_{i j}\right)($ Total Trade Value $)$} & \multicolumn{3}{c|}{$\boldsymbol{R P}_{i j}$ (Ratio of Parts and Components) } \\
\hline Year & 2009 & 2010 & 2011 & 2012 & 2009 & 2010 & 2011 & 2012 \\
\hline Mean & 9.190 & 9.150 & 9.241 & 9.336 & 0.326 & 0.251 & 0.305 & 0.249 \\
\hline Median & 9430 & 9.512 & 9.454 & 9.597 & 0.265 & 0.220 & 0.247 & 0.216 \\
\hline Maximum & 16.487 & 16.853 & 16.968 & 16.984 & 1.000 & 1.000 & 1.000 & 1.000 \\
\hline Minimum & 0.000 & 0.000 & 0.000 & 0.000 & 0.000 & 0.000 & 0.000 & 0.000 \\
\hline Standard Deviation & 2.673 & 2.868 & 2.859 & 2.760 & 0.247 & 0.184 & 0.245 & 0.186 \\
\hline Observations & 858 & 887 & 895 & 896 & 858 & 887 & 895 & 896 \\
\hline
\end{tabular}


Table 4. Summary of the variables for GDP, GDP per capita, and Distance

\begin{tabular}{|c|c|c|c|c|c|c|c|c|c|}
\hline & \multicolumn{4}{|c|}{$\operatorname{In}\left(G D P_{i} G D P_{j}\right)$} & \multicolumn{4}{|c|}{$\operatorname{In}\left(G D P P C_{i} G D P P C_{j}\right)$} & \multirow{2}{*}{$\operatorname{In}\left(D I S T_{i j}\right)$} \\
\hline Year & 2009 & 2010 & 2011 & 2012 & 2009 & 2010 & 2011 & 2012 & \\
\hline Mean & 46.870 & 47.027 & 47.217 & 47.171 & 12.550 & 12.677 & 12.890 & 19.734 & 8.490 \\
\hline Median & 46.770 & 46.990 & 47.187 & 47.161 & 12.738 & 12.879 & 13.078 & 19.917 & 8.984 \\
\hline Maximum & 52.639 & 52.803 & 53.053 & 53.214 & 15.124 & 15.198 & 15.458 & 22.391 & 11.881 \\
\hline Minimum & 41.387 & 41.341 & 41.617 & 41.556 & 7.254 & 7.460 & 7.678 & 14.681 & 4.394 \\
\hline $\begin{array}{l}\text { Standard } \\
\text { Deviation }\end{array}$ & 1.818 & 1.855 & 1.858 & 1.873 & 1.491 & 1.439 & 1.412 & 1.400 & 1.065 \\
\hline Observations & 887 & 893 & 895 & 896 & 887 & 893 & 895 & 896 & 896 \\
\hline
\end{tabular}

Focusing on the ratio of parts and components in Table 3, significant differences among the three groups of HS84, HS85, and HS90 are shown. The mean of this ratio obtained from more than 850 pair countries is biggest for HS85, with the number ranging from 0.546 to 0.606 ; the mean is smallest for HS90, ranging from 0.249 to 0.326 . This suggests that an international production fragmentation arrangement is most developed in HS85 and least developed in HS90 for the environmental goods. This fact confined only to environmental goods conforms to the more general findings of Ando and Kimura (2013), stating that international production fragmentation is most developed in electrical machineries.

\section{Results}

This section summarizes the main empirical results. Subsection A investigates the results of cross-section analysis from 2009 to 2012, and Subsection B discusses the results of panel analysis using pooled data to verify the hypotheses.

\section{A. Results of cross-section analysis}

Tables 5, Table 6, and Table 7 report the gravity equation estimates by OLS for the 
three groups of environmental goods belonging to HS84, HS85, and HS90, respectively. For all the estimations, the dependent variable is the log of sum of bilateral trade values $\ln T_{i j}$ for 43 countries, and the explanatory variables are the log of GDP product $\ln \left(G D P_{i j}\right)$, the $\log$ of GDP per capita product, $\ln \left(G D P P C_{i j}\right)$, the $\log$ of the distance between two countries, $\ln \left(D I S T_{i j}\right)$, and the Dummy variable of Common Language $(D C L)$. In the estimation of Equation (2), the trade ratio of parts and components $\left(R P_{i j}\right)$ and the regional Dummy variables for APEC (DAPEC), 15 EU countries until the fourth enlargement $(D E U R)$, NAFTA (DNAFTA), and Japan-ASEAN FTA (DJASN) are included, as shown in Section IV. On the other hand, for Equation (3) as shown in Section III, instead of introducing four regional dummy variables and the trade ratio of parts and components separately, the product of the trade ratio of parts and components and each regional dummy variable DAPEC $\left(D A P E C^{*} R P\right)$, DEUR $\left(D E U R^{*} R P\right)$, DNAFTA $\left(D N A F T A^{*} R P\right)$, and DJASN $\left(D J A S N^{*} R P\right)$ for explanatory variables are introduced.

As the dummy variable of NAFTA is not significant in all the estimated results, this is omitted in the final estimations shown in all the tables in this section. The coefficient for NAFTA is also insignificant in Frankel (1997), who explains that this fact could be due in part to the small number of observations, which were obtained from only three pairs of countries in NAFTA.

We report the empirical results by comparing the three commodity groups of HS84, HS85, and HS90 to determine the commodity characteristics, and by comparing the four years to find out the evolution of the trade characteristics of environmental goods. The adjusted $R$-squared is obtained with sizes of 0.67 and 0.68 for HS84 and HS90, which are reasonable compared with previous studies of similar specification such as Frankel (1997) and Möhlmann et al. (2010), and slightly low for the HS85 group with a size between 0.505 and 0.589 except in 2009, compared with the other two commodity groups. 
Table 5(a). Results for HS84

\begin{tabular}{|c|c|c|c|c|}
\hline & \multicolumn{4}{|c|}{ Dependent variable: $\log$ of trade value between two countries } \\
\hline & \multicolumn{2}{|c|}{2009} & \multicolumn{2}{|c|}{2010} \\
\hline & Equation (2) & Equation (3) & Equation (2) & Equation (3) \\
\hline Constant & $\begin{array}{l}-36.854^{* * *} \\
(-26.943)\end{array}$ & $\begin{array}{l}-36.169^{* * *} \\
(-26.180)\end{array}$ & $\begin{array}{l}-34.455^{* * *} \\
(-25.349)\end{array}$ & $\begin{array}{l}-34.210^{* * *} \\
(-24.942)\end{array}$ \\
\hline $\ln \left(G D P_{i j}\right)$ & $\begin{array}{l}1.075^{\text {**** }} \\
(36.980)\end{array}$ & $\begin{array}{l}1.074 \\
(36.419)\end{array}$ & $\begin{array}{l}1.047^{\text {**** }} \\
(35.593)\end{array}$ & $\begin{array}{l}1.050 \\
(35.518)\end{array}$ \\
\hline $\ln \left(G D P P C_{i j}\right)$ & $\begin{array}{l}0.259^{* * * *} \\
(6.720)\end{array}$ & $\begin{array}{l}0.233^{\text {**** }} \\
(6.037)\end{array}$ & $\begin{array}{c}0.224^{* * * *} \\
(5.571)^{* * *}\end{array}$ & $\begin{array}{l}0.209^{* * *} \\
(5.251)\end{array}$ \\
\hline $\ln \left(D I S T_{i j}\right)$ & $\begin{array}{l}-0.932^{* * *} \\
(-17.114)\end{array}$ & $\begin{array}{l}-0.917^{* * *} \\
(-16.824)\end{array}$ & $\begin{array}{c}-0.999 \\
(-17.982)\end{array}$ & $\begin{array}{l}-0.985^{* * *} \\
(-17.853)\end{array}$ \\
\hline$D A P E C$ & $\begin{array}{l}0.581^{* * * *} \\
(3.643)\end{array}$ & & $\begin{array}{l}0.626^{* * * *} \\
(3.835)\end{array}$ & \\
\hline DEUR & $\begin{array}{l}-0.657^{* * *} \\
(-3.304)\end{array}$ & & $\begin{array}{l}-0.539 \\
(-2.670)\end{array}$ & \\
\hline$D J A S N$ & $\begin{array}{l}1.683^{* * *} \\
(4.574)\end{array}$ & & $\begin{array}{l}1.652^{* * * *} \\
(4.394)\end{array}$ & \\
\hline$R P_{i j}$ & $\begin{array}{l}0.942^{* * *} \\
(4.737)\end{array}$ & & $\begin{array}{l}0.355^{* * * *} \\
(2.577)\end{array}$ & \\
\hline$D A P E C * R P_{i j}$ & & $\begin{array}{l}1.529^{* * * *} \\
(4.695)\end{array}$ & & $\begin{array}{l}1.488^{* * *} \\
(3.974)\end{array}$ \\
\hline$D E U R * R P_{i j}$ & & $\begin{array}{l}-0.875^{* *} \\
(-2.207)\end{array}$ & & $\begin{array}{c}-0.756 \\
(-1.868)\end{array}$ \\
\hline$D J A S N * R P_{i j}$ & & $\begin{array}{l}2.407^{* * *} \\
(3.230)\end{array}$ & & $\begin{array}{l}2.397^{* * *} \\
(3.305)\end{array}$ \\
\hline$D C L$ & $\begin{array}{c}0.262 \\
(1.475) \\
\end{array}$ & $\begin{array}{c}0.231 \\
(1.286) \\
\end{array}$ & $\begin{array}{c}0.187 \\
(1.033) \\
\end{array}$ & \\
\hline Adjusted $\mathrm{R}^{2}$ & 0.688 & 0.681 & 0.674 & 0.669 \\
\hline Observations & 887 & 887 & 895 & 895 \\
\hline
\end{tabular}

(Note) Figures in parentheses are $t$-value. *** indicates the results are statistically significant at the $1 \%$ level, $* *$ at the $5 \%$ level, * at the $10 \%$ level.

(Source) Author's calculation. 
Table 5(b). Results for HS84

\begin{tabular}{|c|c|c|c|c|}
\hline & \multicolumn{4}{|c|}{ Dependent variable: $\log$ of trade value between two countries } \\
\hline & \multicolumn{2}{|c|}{2011} & \multicolumn{2}{|c|}{2012} \\
\hline & Equation (2) & Equation (3) & Equation (2) & Equation (3) \\
\hline Constant & $\begin{array}{l}-33.790^{* * *} \\
(-25.701)\end{array}$ & $\begin{array}{l}-33.918^{* * *} \\
(-25.823)\end{array}$ & $\begin{array}{l}-35.712^{* * *} \\
(-25.858)\end{array}$ & $\begin{array}{l}-35.597^{* * *} \\
(-25.816)\end{array}$ \\
\hline $\ln \left(G D P_{i j}\right)$ & $\begin{array}{l}1.024 \\
(36.877)\end{array}$ & $\begin{array}{l}1.030 \\
(37.069)\end{array}$ & $\begin{array}{l}1.043^{2} \\
(37.599)\end{array}$ & $\begin{array}{l}1.046 \\
(37.935)\end{array}$ \\
\hline $\ln \left(G D P P C_{i j}\right)$ & $\begin{array}{l}0.243^{\alpha \times *} \\
(6.323)\end{array}$ & $\begin{array}{l}0.219^{* * \times x} \\
(5.764)\end{array}$ & $\begin{array}{l}0.225^{* * 1} \\
(5.866)\end{array}$ & $\begin{array}{l}0.218^{* * *} \\
(5.686)\end{array}$ \\
\hline $\ln \left(D I S T_{i j}\right)$ & $\begin{array}{l}-0.940^{* * * * x} \\
(-17.881)\end{array}$ & $\begin{array}{c}-0.929^{*+1} \\
(-17.838)\end{array}$ & $\begin{array}{l}-0.997^{*+4 *} \\
(-18.893)\end{array}$ & $\begin{array}{l}-0.991^{* * \pi} \\
(-19.038)\end{array}$ \\
\hline$D A P E C$ & $\begin{array}{l}0.454^{* * \alpha *} \\
(2.924)\end{array}$ & & $\begin{array}{l}0.366 \\
(2.368)\end{array}$ & \\
\hline DEUR & $\begin{array}{l}-0.622^{* * *} \\
(-3.258)\end{array}$ & & $\begin{array}{l}-0.718^{* * * * *} \\
(-3.770)\end{array}$ & \\
\hline$D J A S N$ & $\begin{array}{l}1.526 \\
(4.286)\end{array}$ & & $\begin{array}{l}1.789^{* * \times 1} \\
(5.026)\end{array}$ & \\
\hline$R P_{i j}$ & $\begin{array}{c}-0.190 \\
(-0.964)\end{array}$ & & $\begin{array}{c}0.320 \\
(1.572)\end{array}$ & \\
\hline$D A P E C * R P_{i j}$ & & $\begin{array}{l}0.788^{* *} \\
(2.291)\end{array}$ & & $\begin{array}{l}0.981 \\
(2.981)\end{array}$ \\
\hline$D E U R * R P_{i j}$ & & $\begin{array}{l}-1.079^{* * * *} \\
(-2.794)\end{array}$ & & $\begin{array}{l}-1.236^{* \ldots *} \\
(-3.345)\end{array}$ \\
\hline$D J A S N^{*} R P_{i j}$ & & $\begin{array}{l}2.827^{* *+4 x} \\
(3.997)\end{array}$ & & $\begin{array}{l}2.756^{* * * 3} \\
(4.303)\end{array}$ \\
\hline$D C L$ & $\begin{array}{c}0.282 \\
(1.645)\end{array}$ & $\begin{array}{c}0.305^{*} \\
(1.774)\end{array}$ & $\begin{array}{c}0.255 \\
(1.481)\end{array}$ & $\begin{array}{c}0.208 \\
(1.207)\end{array}$ \\
\hline Adjusted $\mathrm{R}^{2}$ & 0.681 & 0.678 & 0.688 & 0.687 \\
\hline Observations & 888 & 888 & 893 & 893 \\
\hline
\end{tabular}

(Note) Figures in parentheses are $t$-value. $* * *$ indicates the results are statistically significant at the $1 \%$ level, ** at the $5 \%$ level, * at the $10 \%$ level.

(Source) Author's calculation. 
Table 6(a). Results for HS85

\begin{tabular}{|c|c|c|c|c|}
\hline & \multicolumn{4}{|c|}{ Dependent variable: log of trade value between two countries } \\
\hline & \multicolumn{2}{|c|}{2009} & \multicolumn{2}{|c|}{2010} \\
\hline & Equation (2) & Equation (3) & Equation (2) & Equation (3) \\
\hline Constant & $\begin{array}{l}-33.963^{* * *} \\
(-19.697)\end{array}$ & $\begin{array}{l}-37.255^{* * *} \\
(-21.400)\end{array}$ & $\begin{array}{l}-30.041^{* * *} \\
(-16.638)\end{array}$ & $\begin{array}{l}-33.599^{* * *} \\
(-17.855)\end{array}$ \\
\hline $\ln \left(G D P_{i j}\right)$ & $\begin{array}{l}1.016^{* * *} \\
(29.061)\end{array}$ & $\begin{array}{l}1.117^{* * *} \\
(30.415)\end{array}$ & $\begin{array}{l}0.997^{* * *} \\
(25.604)\end{array}$ & $\begin{array}{l}1.061^{* * *} \\
(26.310)\end{array}$ \\
\hline $\ln \left(G D P P C_{i j}\right)$ & $\begin{array}{l}0.185^{* * * *} \\
(3.920)\end{array}$ & $\begin{array}{l}0.178^{* * * *} \\
(3.661)\end{array}$ & $\begin{array}{l}0.153^{* * *} \\
(3.010)\end{array}$ & $\begin{array}{l}0.137^{* *} \\
(2.554)\end{array}$ \\
\hline $\ln \left(D I S T_{i j}\right)$ & $\begin{array}{l}-1.017^{* * *} \\
(-15.257)\end{array}$ & $\begin{array}{l}-1.039^{* * *} \\
(-15.705)\end{array}$ & $\begin{array}{l}-1.043^{* * *} \\
(-14.644)\end{array}$ & $\begin{array}{l}-1.081 \\
(-15.087)\end{array}$ \\
\hline$D A P E C$ & $\begin{array}{l}0.707^{* * *} \\
(3.625)\end{array}$ & & $\begin{array}{l}0.635^{* * *} \\
(3.038)\end{array}$ & \\
\hline DEUR & $\begin{array}{l}-3.475^{* * *} \\
(-3.304)\end{array}$ & & $\begin{array}{l}-0.902^{* * * *} \\
(-3.516)\end{array}$ & \\
\hline$D J A S N$ & $\begin{array}{l}1.492^{* * *} \\
(3.321)\end{array}$ & & $\begin{array}{l}1.448^{* * * *} \\
(3.046)\end{array}$ & \\
\hline$R P_{i j}$ & $\begin{array}{l}-1.477^{* * *} \\
(-7.744)\end{array}$ & & $\begin{array}{l}-1.974^{* * *} \\
(-10.103)\end{array}$ & \\
\hline$D A P E C * R P_{i j}$ & & $\begin{array}{c}0.554^{*} \\
(1.812)\end{array}$ & & $\begin{array}{c}0.418 \\
(1.172)\end{array}$ \\
\hline$D E U R^{*} R P_{i j}$ & & $\begin{array}{l}-1.552^{* * *} \\
(-3.806)\end{array}$ & & $\begin{array}{l}-1.747^{* * *} \\
(-3.589)\end{array}$ \\
\hline$D J A S N^{*} R P_{i j}$ & & $\begin{array}{l}2.155^{* * *} \\
(3.156)\end{array}$ & & $\begin{array}{l}1.868^{* *} \\
(2.424)\end{array}$ \\
\hline$D C L$ & $\begin{array}{c}0.687 \\
(3.173) \\
\end{array}$ & $\begin{array}{l}0.712^{* * * *} \\
(3.193)\end{array}$ & $\begin{array}{c}0.398^{*} \\
(1.730) \\
\end{array}$ & $\begin{array}{c}0.333 \\
(1.380)\end{array}$ \\
\hline Adjusted $\mathrm{R}^{2}$ & 0.624 & 0.681 & 0.567 & 0.511 \\
\hline Observations & 879 & 879 & 875 & 875 \\
\hline
\end{tabular}

(Note) Figures in parentheses are $t$-value. *** indicates the results are statistically significant at the $1 \%$ level, ** at the $5 \%$ level, * at the $10 \%$ level.

(Source) Author's calculation. 
Table 6(b). Results for HS85

\begin{tabular}{|c|c|c|c|c|}
\hline & \multicolumn{4}{|c|}{ Dependent variable: log of trade value between two countries } \\
\hline & \multicolumn{2}{|c|}{2011} & \multicolumn{2}{|c|}{2012} \\
\hline & Equation (2) & Equation (3) & Equation (2) & Equation (3) \\
\hline Constant & $\begin{array}{l}-28.635^{* * *} \\
(-16.491)\end{array}$ & $\begin{array}{l}-31.595^{* * *} \\
(-17.599)\end{array}$ & $\begin{array}{l}-31.267^{* * *} \\
(-17.260)\end{array}$ & $\begin{array}{l}-34.069^{* *} \\
(-18.249)\end{array}$ \\
\hline $\ln \left(G D P_{i j}\right)$ & $\begin{array}{l}0.959^{-} \\
(25.992)\end{array}$ & $\begin{array}{l}1.014 \\
(26.682)\end{array}$ & $\begin{array}{l}0.998 \\
(27.355)\end{array}$ & $\begin{array}{l}1.042 \\
(27.796)\end{array}$ \\
\hline $\ln \left(G D P P C_{i j}\right)$ & $\begin{array}{l}0.160^{*} \\
(3.225)\end{array}$ & $\begin{array}{l}0.143^{* * *} \\
(2.786)\end{array}$ & $\begin{array}{l}0.172^{* * *} \\
(3.466)\end{array}$ & $\begin{array}{l}0.170^{* * 8 *} \\
(3.320)\end{array}$ \\
\hline $\ln \left(D I S T_{i j}\right)$ & $\begin{array}{l}-1.049^{* * * *} \\
(-15.283)\end{array}$ & $\begin{array}{l}-1.083^{* * *} \\
(-15.855)\end{array}$ & $\begin{array}{l}-1.115^{*+1+x+1} \\
(-16.275)\end{array}$ & $\begin{array}{l}-1.133^{k * *} \\
(-16.805)\end{array}$ \\
\hline DAPEC & $\begin{array}{l}0.594^{2 * x} \\
(2.945)\end{array}$ & & $\begin{array}{l}0.575^{*} \\
(2.888)\end{array}$ & \\
\hline DEUR & $\begin{array}{l}-0.640 \\
(-2.596)\end{array}$ & & $\begin{array}{l}-0.787^{20 *} \\
(-3.208)\end{array}$ & \\
\hline DJASN & $\begin{array}{l}1.547^{* * 4 *} \\
(3.364)\end{array}$ & & $\begin{array}{l}1.490 \\
(3.264)\end{array}$ & \\
\hline$R P_{i j}$ & $\begin{array}{c}-1.551 \\
(-9.387)\end{array}$ & & $\begin{array}{l}-1.648 \\
(-8.469)\end{array}$ & \\
\hline$D A P E C^{*} R P_{i j}$ & & $\begin{array}{l}0.858 \\
(2.337)\end{array}$ & & $\begin{array}{c}0.542 \\
(1.562)\end{array}$ \\
\hline$D E U R^{*} R P_{i j}$ & & $\begin{array}{c}-1.266 \\
(-3.167)\end{array}$ & & $\begin{array}{l}-1.440^{* * *} \\
(-3.236)\end{array}$ \\
\hline$D J A S N^{*} R P_{i j}$ & & $\begin{array}{l}2.216 \\
(2.759)\end{array}$ & & $\begin{array}{l}2.038^{* * *} \\
(2.655)\end{array}$ \\
\hline$D C L$ & $\begin{array}{l}0.560 \\
(2.522)\end{array}$ & $\begin{array}{l}0.530^{* * * *} \\
(2.287)\end{array}$ & $\begin{array}{l}0.437^{*} \\
(1.941)\end{array}$ & $\begin{array}{c}0.208 \\
(1.902)\end{array}$ \\
\hline Adjusted $\mathrm{R}^{2}$ & 0.576 & 0.528 & 0.589 & 0.549 \\
\hline Observations & 876 & 876 & 879 & 879 \\
\hline
\end{tabular}

(Note) Figures in parentheses are $t$-value. $* * *$ indicates the results are statistically significant at the $1 \%$ level, ** at the $5 \%$ level, * at the $10 \%$ level.

(Source) Author's calculation. 
Table 7(a). Results for HS90

\begin{tabular}{|c|c|c|c|c|}
\hline & \multicolumn{4}{|c|}{ Dependent variable: $\log$ of trade value between two countries } \\
\hline & \multicolumn{2}{|c|}{2009} & \multicolumn{2}{|c|}{2010} \\
\hline & Equation (2) & Equation (3) & Equation (2) & Equation (3) \\
\hline Constant & $\begin{array}{l}-38.906^{* * *} \\
(-25.333)\end{array}$ & $\begin{array}{l}-37.581^{* * *} \\
(-23.983)\end{array}$ & $\begin{array}{l}-38.208^{* * *} \\
(-25.073)\end{array}$ & $\begin{array}{c}-38.375^{* * *} \\
(-25.331)\end{array}$ \\
\hline $\ln \left(G D P_{i j}\right)$ & $\begin{array}{l}1.055^{*} \\
(32.153)\end{array}$ & $\begin{array}{l}1.052^{*} \\
(32.377)\end{array}$ & $\begin{array}{l}1.074^{*} \\
(32.513)\end{array}$ & $\begin{array}{l}1.085^{*} \\
(33.213)\end{array}$ \\
\hline $\ln \left(G D P P C_{i j}\right)$ & $\begin{array}{l}0.427^{* * * *} \\
(9.801)\end{array}$ & $\begin{array}{l}0.355^{\text {**** }} \\
(8.429)\end{array}$ & $\begin{array}{l}0.415^{\text {*** }} \\
(9.270)\end{array}$ & $\begin{array}{l}0.370 \\
(8.452)\end{array}$ \\
\hline $\ln \left(D I S T_{i j}\right)$ & $\begin{array}{l}-0.860 \\
(-14.023)\end{array}$ & $\begin{array}{l}-0.864 \\
(-12.744)\end{array}$ & $\begin{array}{l}-1.004 \\
(-16.249)\end{array}$ & $\begin{array}{l}-0.982^{* * *} \\
(-16.253)\end{array}$ \\
\hline$D A P E C$ & $\begin{array}{l}0.758^{* * *} \\
(4.385)\end{array}$ & & $\begin{array}{l}0.946^{* * *} \\
(5.243)\end{array}$ & \\
\hline DEUR & $\begin{array}{l}-1.031 \\
(-4.812)\end{array}$ & & $\begin{array}{l}-0.849^{* * *} \\
(-3.815)\end{array}$ & \\
\hline$D J A S N$ & $\begin{array}{l}1.676^{* * * *} \\
(4.028)\end{array}$ & & $\begin{array}{l}1.827^{* * * *} \\
(4.366)\end{array}$ & \\
\hline$R P_{i j}$ & $\begin{array}{l}0.555^{* *} \\
(2.403)\end{array}$ & & $\begin{array}{c}-0.273 \\
(-0.860)\end{array}$ & \\
\hline$D A P E C^{*} R P_{i j}$ & & $\begin{array}{l}2.756^{* * *} \\
(5.790)\end{array}$ & & $\begin{array}{c}2.981^{* * * *} \\
5.064\end{array}$ \\
\hline$D E U R * R P_{i j}$ & & $\begin{array}{l}-1.000^{* *} \\
(-2.512)\end{array}$ & & $\begin{array}{l}-2.344^{* * *} \\
(-3.620)\end{array}$ \\
\hline$D J A S N^{*} R P_{i j}$ & & $\begin{array}{l}3.168^{* * *} \\
(3.137)\end{array}$ & & $\begin{array}{l}2.233^{* *} \\
(2.245)\end{array}$ \\
\hline$D C L$ & $\begin{array}{l}0.797^{* * *} \\
(3.986)\end{array}$ & $\begin{array}{l}0.845^{* * * *} \\
(4.212)\end{array}$ & $\begin{array}{l}0.588^{* * *} \\
(2.945)\end{array}$ & $\begin{array}{l}0.622^{* * *} \\
(3.106)\end{array}$ \\
\hline Adjusted $\mathrm{R}^{2}$ & 0.658 & 0.648 & 0.657 & 0.652 \\
\hline Observations & 888 & 888 & 887 & 887 \\
\hline
\end{tabular}

(Note) Figures in parentheses are $t$-value. *** indicates the results are statistically significant at the $1 \%$ level, ** at the $5 \%$ level, * at the $10 \%$ level.

(Source) Author's calculation. 
Table 7(b). Results for HS90

\begin{tabular}{|c|c|c|c|c|}
\hline & \multicolumn{4}{|c|}{ Dependent variable: $\log$ of trade value between two countries } \\
\hline & \multicolumn{2}{|c|}{2011} & \multicolumn{2}{|c|}{2012} \\
\hline & Equation (2) & Equation (3) & Equation (2) & Equation (3) \\
\hline Constant & $\begin{array}{l}-37.407^{* * *} \\
(-25.412)\end{array}$ & $\begin{array}{l}-38.092^{* * *} \\
(-25.726)\end{array}$ & $\begin{array}{l}-38.912^{* * *} \\
(-26.399)\end{array}$ & $\begin{array}{l}-39.063^{* * *} \\
(-26.540)\end{array}$ \\
\hline $\ln \left(G D P_{i j}\right)$ & $\begin{array}{l}1.055^{-3} \\
(33.767)\end{array}$ & $\begin{array}{l}1.077 \\
(34.340)\end{array}$ & $\begin{array}{c}1.040 \\
(35.034)\end{array}$ & $\begin{array}{l}1.051 \\
(35.663)\end{array}$ \\
\hline $\ln \left(G D P P C_{i j}\right)$ & $\begin{array}{l}0.452^{1} \\
(10.503)\end{array}$ & $\begin{array}{l}0.403^{* * *} \\
(9.390)\end{array}$ & $\begin{array}{c}0.377^{* * * *} \\
(9.127)\end{array}$ & $\begin{array}{l}0.354^{3 * 5} \\
(8.605)\end{array}$ \\
\hline $\ln \left(D I S T_{i j}\right)$ & $\begin{array}{l}-1.052^{* x+} \\
(-17.780)\end{array}$ & $\begin{array}{l}-1.035^{2 \times k} \\
(-17.518)\end{array}$ & $\begin{array}{c}-0.993^{* * * *} \\
(-17.366)\end{array}$ & $\begin{array}{l}-0.974^{* a+k} \\
(-17.462)\end{array}$ \\
\hline$D A P E C$ & $\begin{array}{l}0.758^{2} \\
(4.385)\end{array}$ & & $\begin{array}{c}0.887^{1+2 \times x} \\
(5.324)\end{array}$ & \\
\hline DEUR & $\begin{array}{c}-1.031^{* * * * *} \\
(-4.836)\end{array}$ & & $\begin{array}{l}-0.907^{* 1 *} \\
(-4.419)\end{array}$ & \\
\hline$D J A S N$ & $\begin{array}{l}1.988 \\
(4.836)\end{array}$ & & $\begin{array}{l}1.334^{*} \\
(3.458)\end{array}$ & \\
\hline$R P_{i j}$ & $\begin{array}{l}-0.540^{* *} \\
(-2.381)\end{array}$ & & $\begin{array}{c}0.174 \\
(0.602)\end{array}$ & \\
\hline$D A P E C * R P_{i j}$ & & $\begin{array}{l}1.280 \\
(2.772)\end{array}$ & & $\begin{array}{l}2.478 \\
(5.472)\end{array}$ \\
\hline$D E U R^{*} R P_{i j}$ & & $\begin{array}{l}-2.433^{* \cdots *} \\
(-4.645)\end{array}$ & & $\begin{array}{l}-2.442^{* * *} \\
(-4.059)\end{array}$ \\
\hline$D J A S N^{*} R P_{i j}$ & & $\begin{array}{l}3.044^{* * *} \\
(3.495)\end{array}$ & & $\begin{array}{c}1.172 \\
(1.455)\end{array}$ \\
\hline$D C L$ & $\begin{array}{l}0.696^{* *-} \\
(3.607)\end{array}$ & $\begin{array}{l}0.818^{* * * *} \\
(4.205)\end{array}$ & $\begin{array}{l}0.561^{* * * *} \\
(3.030)\end{array}$ & $\begin{array}{l}0.643^{* * * *} \\
(3.486)\end{array}$ \\
\hline Adjusted $R^{2}$ & 0.677 & 0.665 & 0.676 & 0.676 \\
\hline Observations & 895 & 895 & 896 & 896 \\
\hline
\end{tabular}

(Note) Figures in parentheses are $t$-value. $* * *$ indicates the results are statistically significant at the $1 \%$ level, ** at the $5 \%$ level, * at the $10 \%$ level.

(Source) Author's calculation. 


\section{GDP and per capita GDP}

We start by documenting the effects of GDP and GDP per capita. The log of the product of the two countries' GDPs is always highly significant statistically as shown in Tables 6, Table 7, and Table 8, with coefficients around 1 for 4 years in all the HS groups. The estimated coefficient on GDP per capita is also significant statistically at the $1 \%$ level with the coefficients of 0.225 for HS84, 0.172 for HS85, and 0.337 for HS90 in 2012 in Equation (2). This shows the clear differences among the coefficient sizes of GDP per capita for three HS groups, with the largest coefficients for the group of HS90, which implies that the trade of R\&D intensive precision machineries with a high share of final goods is more active among the richer countries with high GDP per capita than poorer ones. For the group of HS85, which has the biggest trade share of parts and components, the effect of GDP per capita on trade for all the four years is smallest in the three groups.

Comparing the results with those of previous studies, Möhlmann et al. (2010) shows a coefficient on the log of the product of GDPs (0.83) and that of the product of GDP per capita (0.57) for the overall trade in the year 2000. Frankel (1997) shows the coefficient of the $\log$ of the product of GDPs being 0.930 and that of the product of GDP per capita being 0.128 , using OLS. Thus the results of this study are quite consistent with those previous studies which have a trend of considerably smaller coefficients on two countries' per capita GDPs than two countries' GDPs.

\section{Distance, common language, and adjacency}

As the estimated coefficient on the dummy variable of adjacency is not significant statistically in all cases, this variable is excluded from the analysis. The estimated coefficients on the log of distance between the capitals of two countries are highly significant statistically with coefficients around -1 .

We confirm that there are differences in the absolute value of the coefficients among the industry groups. The absolute value of the coefficient is less than 1 for all the estimations of the group of HS84, and always bigger than 1 for the group of HS85 whose trade share of parts and components is biggest. This result contradicts the general findings of the previous studies, which show that the parts and components of the HS85 group, namely the group of electrical machineries, have high value per unit volume or 
weight with low transport cost and that consequently the effect of geographical distance on trade is comparatively small. ${ }^{8}$ However, the results of this study, which focuses on the trade of environmental goods, indicate that the effect of distance on trade in the group of HS85 is bigger than in other groups, which suggests that the transport cost is fairly high for the environmental goods belonging to HS85. The result shows that when the distance between two countries is increased by $10 \%$, the trade between them falls by more than $11 \%$ for the HS85 group in 2012.

For the coefficient of the dummy variable of common language $(D C L)$, the results also show differences among the three HS groups. In the group of HS90, the coefficient is statistically significant at the $1 \%$ level in all cases. Although the coefficient shows a downward trend, from 0.797 in 2009 to 0.561 in 2012 in Equation (2), and from 0.845 in 2009 to 0.643 in 2012 in Equation (2), the effect of common language on trade is clarified in the HS90 group. For the HS85 group, the coefficient is 0.687 for Equation (2) and 0.712 for Equation (3) with 1\% level significance in 2009. Afterward, however, both the coefficient and significance level decline, and in 2012 the coefficient is 0.437 with a significance level of $10 \%$ in Equation (2). For the HS84 group, this variable is not statistically significant in every year. As the HS90 group has the largest share of high-tech goods, the implication is that two countries sharing a common language tend to trade roughly $75 \%$ in Equation (2) and $86 \%$ in Equation (2) more than they would otherwise. On the other hand, in the HS85 group, the countries sharing a common language tend to trade about $54 \%$ more than they would otherwise.

\section{Trade share of parts and components, regional dummies}

The trade share of parts and components has a different effect on overall trade among the three HS groups of environmental goods. In the HS84 group, yearly differences can be observed, with the statistically highly significant positive coefficient of 0.942 in 2009 and 0.355 in 2010, which implies production fragmentation where the two countries with a high share of trade in parts and components affecting positively the overall trade. In 2011 and 2012, however, this relationship has no statistical significance.

In the HS85 group, the trade share of parts and components has a negative coefficient

\footnotetext{
${ }^{8}$ Ando and Kimura (2013) clearly show this fact by comparing the trade of electrical machineries with that of transport machineries.

${ }^{9}$ These effects are obtained by $\exp (0.561)=1.752, \exp (0.622)=1.863$, and $\exp (0.429)=1.536$.
} 
with a size between -1.477 and-1.974 and with high statistical significance, implying that two countries with a high share of trade in finished goods trade more. For the group of HS90, the coefficient of trade share of parts and components is a positive number of 0.555 in 2009 , with a statistical significance of $5 \%$, but afterward the coefficients become negative or insignificant statistically.

For the regional dummy variables, in the Equation (2) result for the HS84 group, the dummies for APEC and the Japan-ASEAN FTA are highly significant in all the years, implying that trade is active for the two countries belonging to these regional groups. The estimates suggest that the effect of the Japan-ASEAN FTA is much bigger than that of APEC. Two members of APEC trade 44\% more, and two members of Japan-ASEAN FTA trade about 6 times more, after holding constant for the other variables in the group of HS84. ${ }^{10}$ Similar results are obtained for the group of HS85. Both coefficients of the dummies for APEC and the Japan-ASEAN FTA are statistically significant at the 1\% level, and the coefficient of the dummy variable of the Japan-ASEAN FTA is about two or three times more than that of APEC. In 2012, the coefficient of the dummy variable of APEC is 0.575 and that of the Japan-ASEAN FTA is 1.490 , which suggests that two members of the APEC trade $77 \%$ more, and two members of the Japan-ASEAN FTA trade about 4.4 times more after holding constant for the other variables, than two otherwise similar countries in the group of HS85.

On the other hand, for the group of HS90, the coefficients of the dummy variables of APEC and the Japan-ASEAN FTA are estimated as positive with a statistical significance of $1 \%$ and with a relatively big coefficient of APEC compared with that of HS84 and HS85. In 2012, the coefficient of APEC is 0.887 and that of Japan-ASEAN FTA 1.334, suggesting that two members of APEC trade 2.43 times more, and two members of the Japan-ASEAN FTA trade 3.8 times more than two otherwise similar countries after holding constant for the other variables.

For the dummy variable of EU15 countries, the coefficient is always negative with a statistical significance of $1 \%$, in all the cases of the three groups in all four years. Similar results of a negative coefficient on the EU15 group are obtained in Frankel (1997) using the data of the 1960s, 1970s, and 1992. Frankel (1997) views the reason for this fact being that most of the trade in the EU can be explained by the members' size, level of development, proximity, common borders, and common languages with little intra-EU trade left over, after correcting these influences which are to be attributed to the effect of

\footnotetext{
${ }^{10}$ For the dummy variables, the effects of the APEC and Japan-ASEAN FTA are obtained by $\exp (0.366)=1.442$ and $\exp (1.789)=5.983$, respectively.
} 
the regional trading arrangement itself.

For the results of Equation (3), we see the clear differences among the three HS groups in the estimates of the product of each regional dummy variable and the trade share of parts and components. In the group of HS84, both the product of APEC dummy and trade share of parts and components, $D A P E C^{*} R P$, and the product of the dummy variable of Japan-ASEAN FTA and trade share of parts and components, DJASN*RP, are statistically significant. The coefficient is from 0.79 to 1.56 for the former, and the coefficient is bigger than 2 for the latter, suggesting that the trade in parts and components derived from the international production fragmentation has accelerated the overall trade among ASEAN plus one such as Japan, and also among the APEC countries, although more slowly.

In the group of HS85, the estimated coefficient on the product of trade share of parts and components and dummy variable for Japan-ASEAN FTA is highly significant statistically, between 1.8 to 2.2 in four years, suggesting that production fragmentation is the key factor for trade increase in the environmental goods belonging to HS85 among the member countries of Japan-ASEAN FTA, but the coefficient of the product of trade share of parts and components and dummy variable for APEC is 0.86 with a statistical significance of only 5\% in 2011. In other years the coefficient is not statistically significant. Although the environmental goods belonging to HS85 have the highest trade share of parts and components, we cannot confirm the effect of production fragmentation on trade increase in APEC group for this commodity group.

On the other hand, for the group of HS90, the coefficient of the product of trade share of parts and components and the dummy variable for APEC $\left(D A P E C^{*} R P\right)$ is statistically significant and large compared to the two other groups. In 2009, this coefficient is 2.76 and the coefficient of the product of trade share of parts and components and the dummy variable of the Japan-ASEAN FTA $\left(D J A S N^{*} R P\right)$ is 3.17, but in 2010 the former is 2.98 statistically significant at the $1 \%$ level, which is bigger than the latter at 2.23 , statistically significant at the 5\% level. Contrary to the groups of HS84 and HS85, in 2012, while the coefficient of the product of trade share of parts and components and the dummy variable of Japan-ASEAN FTA are not significant, the coefficient of the product of trade share of parts and components and the dummy variable of APEC is 2.82, which is statistically significant at the $1 \%$ level. As this fact suggests that the international production fragmentation effect on trade increase is strong among the APEC countries including developed countries in the group of HS90, it can be considered as reflected by the high-tech characteristics of this product group. 
The coefficient of the product of trade share of parts and components and the dummy variable of 15 EU countries in Equation (3) are estimated as a highly significant negative number in all years for all three commodity groups, suggesting that trade is bigger for two countries with a smaller share of trade in parts and components within the EU15; in other words the trade of final goods is leading the overall trade among EU15. The coefficients of this variable for HS84, HS85, and HS90 in 2012 are -1.236, -1.440, and -2.442 , respectively, statistically significant at a $1 \%$ level.

\section{B. Results of panel analysis}

The panel analysis is useful for investigating the robust effects of the explanatory variables across 4 years for each of the three commodity groups. Tables 8 , Table 9 , and Table 10 show the estimation results of panel analysis using the panel OLS and crosssection random effects analysis for the groups of HS84, HS85, and HS90 respectively. The estimation is conducted using two specifications such as Equation (2) and Equation (3), shown in Section III. As there are no big differences between the results using panel OLS and cross-section random effects analysis, we mainly focus on the results of the estimation using cross-section random effects and compare the estimated coefficients among the three groups of HS84, HS85, and HS90 to verify the hypotheses for each of the three groups. 


\section{Table 8. Results for HS84}

\begin{tabular}{|c|c|c|c|c|}
\hline & \multicolumn{4}{|c|}{ Dependent variable: log of trade value between two countries } \\
\hline & \multicolumn{2}{|c|}{ Equation (2) } & \multicolumn{2}{|c|}{ Equation (3) } \\
\hline & $\begin{array}{l}\text { Panel } \\
\text { OLS }\end{array}$ & $\begin{array}{c}\text { CrossSection } \\
\text { Random }\end{array}$ & $\begin{array}{l}\text { Panel } \\
\text { OLS }\end{array}$ & $\begin{array}{c}\text { CrossSection } \\
\text { Random }\end{array}$ \\
\hline Constant & $\begin{array}{l}-33.093^{* * *} \\
(-49.925)\end{array}$ & $\begin{array}{l}-31.004^{* * *} \\
(-27.897)\end{array}$ & $\begin{array}{l}-33.838^{* * *} \\
(-49.5875)\end{array}$ & $\begin{array}{l}-30.748^{* * *} \\
(-27.895)\end{array}$ \\
\hline $\ln \left(G D P_{i j}\right)$ & $\begin{array}{l}1.081^{* * *} \\
(75.834)\end{array}$ & $\begin{array}{l}1.039^{* * * *} \\
(44.024)\end{array}$ & $\begin{array}{l}1.078^{* * * *} \\
(75.663)\end{array}$ & $\begin{array}{l}1.035^{* * *} \\
(44.266)\end{array}$ \\
\hline $\ln \left(G D P P C_{i j}\right)$ & $\begin{array}{c}-0.003 \\
(-1.425)\end{array}$ & $\begin{array}{l}-0.003 \\
(-4.085)\end{array}$ & $\begin{array}{l}-0.003 \\
(-1.477)\end{array}$ & $\begin{array}{l}-0.003^{* * * *} \\
(-4.128)\end{array}$ \\
\hline $\ln \left(D I S T_{i j}\right)$ & $\begin{array}{l}-0.998^{* * *} \\
(-36.494)\end{array}$ & $\begin{array}{l}-0.999^{* * *} \\
(-20.315)\end{array}$ & $\begin{array}{l}-0.981 \\
(-36.240)\end{array}$ & $\begin{array}{l}-0.982^{* * *} \\
(-21.186)\end{array}$ \\
\hline$D A P E C$ & $\begin{array}{l}0.418^{* * * 4} \\
(5.201)\end{array}$ & $\begin{array}{l}0.428^{* * * *} \\
(2.960)\end{array}$ & & \\
\hline DEUR & $\begin{array}{l}-0.316 \\
(-3.282)\end{array}$ & $\begin{array}{l}-0.256 \\
(-1.476)\end{array}$ & & \\
\hline$D J A S N$ & $\begin{array}{l}1.271^{* * *} \\
(6.942)\end{array}$ & $\begin{array}{l}1.283^{* * *} \\
(3.877)\end{array}$ & & \\
\hline$R P_{i j}$ & $\begin{array}{l}0.420 \\
(4.708)\end{array}$ & $\begin{array}{l}0.157^{* * *} \\
(2.741)\end{array}$ & & \\
\hline$D A P E C * R P_{i j}$ & & & $\begin{array}{l}1.092^{* * *} \\
(6.294)\end{array}$ & $\begin{array}{l}0.525^{* * *} \\
(2.694)\end{array}$ \\
\hline$D E U R * R P_{i j}$ & & & $\begin{array}{l}-0.414^{* *-} \\
(-2.166)\end{array}$ & $\begin{array}{l}-0.155 \\
(-0.551)\end{array}$ \\
\hline$D J A S N^{*} R P_{i j}$ & & & $\begin{array}{l}1.969^{* * *} \\
(5.960)\end{array}$ & $\begin{array}{l}1.306^{* * *} \\
(2.896)\end{array}$ \\
\hline$D C L$ & $\begin{array}{l}0.347^{* * *} \\
(3.895)\end{array}$ & $\begin{array}{l}0.400 \\
(2.476)\end{array}$ & $\begin{array}{l}0.317^{* * * *} \\
(3.535)\end{array}$ & $\begin{array}{l}0.442^{* * *} \\
(2.801)\end{array}$ \\
\hline Adjusted $\mathrm{R}^{2}$ & 0.670 & 0.399 & 0.668 & 0.394 \\
\hline Observations & 3563 & 3563 & 3563 & 3563 \\
\hline
\end{tabular}

(Note) Figures in parentheses are $t$-value. $* * *$ indicates the results are statistically significant at the $1 \%$ level, $* *$ at the $5 \%$ level, * at the $10 \%$ level.

(Source) Author's calculation. 


\section{Table 9. Results for HS85}

\begin{tabular}{|c|c|c|c|c|}
\hline & \multicolumn{4}{|c|}{ Dependent variable: log of trade value between two countries } \\
\hline & \multicolumn{2}{|c|}{ Equation (2) } & \multicolumn{2}{|c|}{ Equation (3) } \\
\hline & $\begin{array}{l}\text { Panel } \\
\text { OLS }\end{array}$ & $\begin{array}{c}\text { CrossSection } \\
\text { Random }\end{array}$ & $\begin{array}{l}\text { Panel } \\
\text { OLS }\end{array}$ & $\begin{array}{c}\text { CrossSection } \\
\text { Random }\end{array}$ \\
\hline Constant & $\begin{array}{l}-29.437^{* * *} \\
(-34.462)\end{array}$ & $\begin{array}{l}-29.196^{* * *} \\
(-20.596)\end{array}$ & $\begin{array}{l}-32.776^{* * *} \\
(-37.259)\end{array}$ & $\begin{array}{l}-32.019^{* * *} \\
(-22.173)\end{array}$ \\
\hline $\ln \left(G D P_{i j}\right)$ & $\begin{array}{l}1.021^{* * *} \\
(55.516)\end{array}$ & $\begin{array}{l}1.027^{* * *} \\
(34.411)\end{array}$ & $\begin{array}{l}1.074^{* * * *} \\
(56.944)\end{array}$ & $\begin{array}{l}1.065^{* * *} \\
(34.712)\end{array}$ \\
\hline $\ln \left(G D P P C_{i j}\right)$ & $\begin{array}{c}0.012 \\
(1.265)\end{array}$ & $\begin{array}{l}-0.012^{* *} \\
(-2.117)\end{array}$ & $\begin{array}{c}0.009 \\
(0.903)\end{array}$ & $\begin{array}{l}-0.010^{*} \\
(-1.773)\end{array}$ \\
\hline $\ln \left(D I S T_{i j}\right)$ & $\begin{array}{l}-1.076^{* * *} \\
(-31.270)\end{array}$ & $\begin{array}{l}-1.119^{* * * *} \\
(-18.619)\end{array}$ & $\begin{array}{l}-1.076^{* * * *} \\
(-32.247)\end{array}$ & $\begin{array}{l}-1.088^{* * * *} \\
(-19.391)\end{array}$ \\
\hline$D A P E C$ & $\begin{array}{l}0.567^{* * *} \\
(5.635)\end{array}$ & $\begin{array}{l}0.603^{* * * *} \\
(3.419)\end{array}$ & $\begin{array}{l}0.522^{* * * *} \\
(3.044)\end{array}$ & \\
\hline DEUR & $\begin{array}{l}-0.579^{* * *} \\
(-4.801)\end{array}$ & $\begin{array}{l}-0.522^{* * *} \\
(-2.464)\end{array}$ & & \\
\hline$D J A S N$ & $\begin{array}{l}1.244^{* * * *} \\
(5.445)\end{array}$ & $\begin{array}{l}1.179^{* * * *} \\
(2.925)\end{array}$ & & \\
\hline$R P_{i j}$ & $\begin{array}{l}-1.666^{* * *} \\
(-17.946)\end{array}$ & $\begin{array}{l}-1.405^{* * *} \\
(-19.075)\end{array}$ & & \\
\hline$D A P E C^{*} R P_{i j}$ & $\begin{array}{l}0.567^{* * * *} \\
(5.635)\end{array}$ & $\begin{array}{l}0.603^{* * * *} \\
(3.419)\end{array}$ & $\begin{array}{l}0.522^{* * *} \\
(3.044)\end{array}$ & $\begin{array}{l}-0.405^{*} \\
(-1.904)\end{array}$ \\
\hline$D E U R^{*} R P_{i j}$ & & & $\begin{array}{l}-0.190^{* * *} \\
(-3.290)\end{array}$ & $\begin{array}{c}-0.048 \\
(-1.278)\end{array}$ \\
\hline$D J A S N^{*} R P_{i j}$ & & & $\begin{array}{l}1.731^{\text {****** }} \\
(4.639)\end{array}$ & $\begin{array}{l}1.310^{* * *} \\
(2.593)\end{array}$ \\
\hline$D C L$ & $\begin{array}{l}0.581^{* * *} \\
(5.226)\end{array}$ & $\begin{array}{l}0.619^{* * * *} \\
(3.151)\end{array}$ & $\begin{array}{l}0.572^{* * * *} \\
(4.940)\end{array}$ & $\begin{array}{l}0.706^{* * *} \\
(3.717)\end{array}$ \\
\hline Adjusted $\mathrm{R}^{2}$ & 0.586 & 0.364 & 0.540 & 0.293 \\
\hline Observations & 3509 & 3509 & 3504 & 3504 \\
\hline
\end{tabular}

(Note) Figures in parentheses are $t$-value. *** indicates the results are statistically significant at the $1 \%$ level, ** at the $5 \%$ level, * at the $10 \%$ level.

(Source) Author's calculation. 


\section{Table 10. Results for HS90}

\begin{tabular}{|c|c|c|c|c|}
\hline & \multicolumn{4}{|c|}{ Dependent variable: log of trade value between two countries } \\
\hline & \multicolumn{2}{|c|}{ Equation (2) } & \multicolumn{2}{|c|}{ Equation (3) } \\
\hline & $\begin{array}{l}\text { Panel } \\
\text { OLS }\end{array}$ & $\begin{array}{c}\text { CrossSection } \\
\text { Random }\end{array}$ & $\begin{array}{l}\text { Panel } \\
\text { OLS }\end{array}$ & $\begin{array}{c}\text { CrossSection } \\
\text { Random }\end{array}$ \\
\hline Constant & $\begin{array}{l}-35.3366^{* * *} \\
(-46.899)\end{array}$ & $\begin{array}{l}-29.503^{* * *} \\
(-24.249)\end{array}$ & $\begin{array}{l}-35.301^{* * *} \\
(-46.963)\end{array}$ & $\begin{array}{c}-29.579^{* * *} \\
(-24.430)\end{array}$ \\
\hline $\ln (G D P i j)$ & $\begin{array}{l}1.101 \\
(67.882)\end{array}$ & $\begin{array}{l}0.992^{* * * *} \\
(38.349)\end{array}$ & $\begin{array}{l}1.103^{* * * * *} \\
(69.073)\end{array}$ & $\begin{array}{l}0.997^{* * *} \\
(39.164)\end{array}$ \\
\hline $\ln (G D P P C i j)$ & $\begin{array}{l}0.071^{* * * *} \\
(8.188)\end{array}$ & $\begin{array}{l}0.016^{* * *} \\
(4.669)\end{array}$ & $\begin{array}{l}0.063^{\text {**** }} \\
(7.235)\end{array}$ & $\begin{array}{l}0.013^{* * *} \\
(4.028)\end{array}$ \\
\hline $\ln (D I S T)$ & $\begin{array}{l}-1.012^{* * *} \\
(-32.601)\end{array}$ & $\begin{array}{l}-0.998^{* * *} \\
(-17.779)\end{array}$ & $\begin{array}{l}-1.002^{* * *} \\
(-32.276)\end{array}$ & $\begin{array}{l}-1.001^{* * *} \\
(-19.894)\end{array}$ \\
\hline$D A P E C$ & $\begin{array}{l}0.796^{* * *} \\
(8.772)\end{array}$ & $\begin{array}{l}0.859^{* * *} \\
(5.209)\end{array}$ & & \\
\hline DEUR & $\begin{array}{l}-0.477^{* * *} \\
(-4.348)\end{array}$ & $\begin{array}{c}-0.232 \\
(-1.172)\end{array}$ & & \\
\hline DJASN & $\begin{array}{l}1.039^{* * *} \\
(4.995)\end{array}$ & $\begin{array}{l}0.926^{* * * *} \\
(2.450)\end{array}$ & & \\
\hline$R P_{i j}$ & $\begin{array}{l}0.306^{* *} \\
(2.330)\end{array}$ & $\begin{array}{l}-0.013 \\
(-0.198)\end{array}$ & & \\
\hline$D A P E C{ }^{*} R P_{i j}$ & & & $\begin{array}{l}2.205^{* * * *} \\
(8.720)\end{array}$ & $\begin{array}{l}0.641^{* * * *} \\
(3.246)\end{array}$ \\
\hline$D E U R * R P_{i j}$ & & & $\begin{array}{l}-0.833^{* * *} \\
(-3.404)\end{array}$ & $\begin{array}{l}-0.541^{* * *} \\
(-3.994)\end{array}$ \\
\hline$D J A S N^{*} R P_{i j}$ & & & $\begin{array}{l}1.311^{* * * *} \\
(2.810)\end{array}$ & $\begin{array}{c}0.062 \\
(0.129)\end{array}$ \\
\hline$D C L$ & $\begin{array}{l}0.816^{* * *} \\
(8.083)\end{array}$ & $\begin{array}{l}0.930^{* * * *} \\
(5.046)\end{array}$ & $\begin{array}{l}0.856^{* * * *} \\
(8.495)\end{array}$ & $\begin{array}{l}1.096^{* * *} \\
(6.046)\end{array}$ \\
\hline Adjusted $\mathrm{R}^{2}$ & 0.640 & 0.357 & 0.636 & 0.350 \\
\hline Observations & 3562 & 3562 & 3562 & 3562 \\
\hline
\end{tabular}

(Note) Figures in parentheses are $t$-value. $* * *$ indicates the results are statistically significant at the $1 \%$ level, ** at the $5 \%$ level, * at the $10 \%$ level.

(Source) Author's calculation. 
The coefficients on the log of the product of the two countries' GDPs are always highly significant statistically, with 1.04 for HS84, 1.03 for HS85, and 0.99 for HS90, respectively. While the estimated coefficients on the product of GDP per capita are statistically insignificant or have the wrong sign for HS84 and HS85, those are significant statistically at a 1\% level with small effects of 0.016 for Equation (2) and 0.013 for Equation (3) for HS90. This confirms the trade pattern we have seen in subsection A that the richer countries do trade the environmental goods belonging to HS90 more than the poor ones because of the high share of high-tech finished goods in HS90.

The estimated coefficient on the log of distance is biggest for the group of HS85, with -1.119 in Equation (2) and -1.088 in Equation (3). Such estimates imply that when the distance is increased by $1 \%$, trade falls by about 1.119 or 1.088 on average, depending on the specification of the gravity equation, suggesting that trade with nearby countries is active by the possible high transportation costs for environmental electric machinery.

On the trade share of parts and components, the estimated coefficients are reflected by the characteristics of the three HS groups. For environmental goods belonging to HS84, the coefficient, 0.157 , is significant statistically at $1 \%$ level, indicating the production fragmentation effect by which trade increases with the trade share of parts and components. On the other hand, for HS85, the estimated coefficient of trade share of parts and components is negative at -1.405 . This means that when trade share of parts and components decreases and that of final goods increases by $1 \%$, trade increases more than proportionately. As the trade share of parts and components is high with more than $50 \%$ in the group of HS 85 possibly by production fragmentation in the past, overall trade might be bigger for two countries with higher trade share of final goods whose prices are relatively expensive. For the group of HS90, the estimated coefficient on this variable is not statistically significant.

On a dummy variable to represent when both countries of a pair speak a common official language, the results show a highly significant effect for all cases of all the HS groups. The coefficients are 0.400 in Equation (2) and 0.442 in Equation (3) for HS84; 0.619 in Equation (2) and 0.706 in Equation (3) for HS85; and 0.930 in Equation (2) and 1.096 in Equation (3) for HS90, suggesting that the effect of common language is quite strong for the environmental group of HS90 with a high share of high-tech industries.

Dummy variables for intraregional trade in APEC and the Japan-ASEAN FTA included in Equation (2) are highly significant statistically. The coefficient of the dummy variable for APEC is biggest at 0.859 in the group of HS90, second biggest at 0.603 for the group of HS85, and smallest at 0.428 for the group of HS84. On the other hand, 
the coefficient of the dummy variable for the Japan-ASEAN FTA is biggest at 1.283 for HS84, second biggest at 1.179 for HS85, and smallest at 0.926 for HS90, indicating that the order is completely opposite. The trade among the members of APEC is active for the HS90 group with a high share of high-tech goods because the APEC members include developed countries, while for the environmental goods of HS85 and HS84 which have a higher trade share of parts and components, trade is more active among the members of the Japan-ASEAN FTA by the fragmentation effect. From those estimation results, the first hypothesis that the trade of environmental goods is accelerated within the regions of APEC and the Japan-ASEAN FTA can be verified with some qualifications reflecting the commodity characteristics. On the other hand, the region of EU15 shows the opposite result: that trade is bigger for the pair countries with a higher share of trade in final goods.

For the product of trade share of parts and components and regional dummy variables of APEC, the Japan-ASEAN FTA, and EU15 included in Equation (3), the estimated results vary across the HS groups of environmental goods, emphasizing the results of the regional dummy variables in Equation (2) already described. For the variable of the product of trade share of parts and components and APEC dummy, while the coefficient is not significant statistically for HS85, it is significant at $1 \%$ level for HS84 and HS90 with 0.525 and 0.641 respectively. Accordingly, the effect of the trade share of parts and components on overall trade among the APEC countries is confirmed for the environmental goods belonging to HS84 and HS90, even with a strong trade effect on the group of HS90. On the other hand, for the product of trade share of parts and components and dummy variable of Japan-ASEAN FTA, contrary to the APEC case, while the coefficient is not significant statistically in the group of environmental goods for HS90, it is 1.310 with significance at the $1 \%$ level for HS85, indicating the relatively strong effect of trade share of parts and components on overall trade among the member countries of Japan-ASEAN FTA in HS85. Although the member countries of APEC and Japan-ASEAN FTA are partly duplicated, differences of the regional effects of trade share of parts and components are clarified together with the characteristics of commodity groups.

By summarizing the results regarding trade share of parts and components together with the regional dummy variables, it is possible to verify the second hypothesis: that the trade of parts and components has the driving force of the trade increase in environmental goods because of the proliferation of complex supply chains networks. By introducing the trade share of parts and components as an explanatory variable in 
the gravity model, the coefficient is only positive and significant statistically for HS84. On the other hand, by introducing the product of trade share of parts and components and dummy variable for the APEC bloc and the Japan-ASEAN FTA, respectively, the effect of trade share of parts and components on overall trade within each region can be confirmed with some qualifications reflecting the characteristics of commodity groups, so that the second hypothesis can be verified by restricting the trade for APEC and the Japan-ASEAN FTA. Thus, the results induced by this study are consistent with earlier papers, making clear the effect of the regional creation of production fragmentation and distribution networks.

\section{Conclusion}

This paper investigates trade structure on the 53 environmental goods listed in the collection of main environmental goods made by APEC in 2012, in the framework of the gravity model, and presents clear evidence that the trade in those environmental goods is expanding rapidly, especially among the APEC countries and the members of the JapanASEAN FTA. Also by introducing the trade share of parts and components in bilateral trade as the explanatory variable, the estimated results of the gravity analysis show that the production fragmentation depending on trade in parts and components is a key factor to expand the overall trade in environmental goods among the APEC countries and the members of the Japan-ASEAN FTA. Those results of the gravity analysis are consistent with the findings in earlier studies dealing with the machinery industries. What is new as a contribution of this study is that the regional trade structure of environmental goods reflecting the fragmented production networks for each of the three commodity groups divided by HS classification has been clarified according to the differences in production technology or trade share of parts and components. The effect of international production fragmentation on trade which is regionally different by examining each commodity group of environmental goods can be summarized as follows. For the group of HS84, the general machinery, the trade in parts and components derived from the international production fragmentation has accelerated the overall trade among ASEAN plus one such as Japan, and also among the APEC countries, although more slowly. For the group of HS85, the electric machinery, production fragmentation is the key factor for trade 
increase of the environmental goods among the member countries of Japan-ASEAN FTA, but not for APEC, although the group of environmental goods of HS85 has the highest trade share of parts and components. For the group of HS90, the international production fragmentation effect on trade increase is strong among the APEC countries including developed countries, reflecting the fact that this group includes the highest number of products with high technology. In fact, the effect of international production fragmentation on trade cannot be clarified for EU until the fourth EU enlargement.

In addition to these results concerning the hypotheses of the study, the conventional explanatory variables in the usual gravity model such as GDP and GDP per capita of the pair countries, distance between the two countries, and dummy variable of common language are found significant statistically, with some qualifications for each commodity group.

The empirical results concerning the active regional trade of the environmental goods in APEC suggest the importance of the commitment by APEC to liberalize trade of environmental goods for expanding regional trade because of the trade potentiality in this region for those goods. Also, the commitment by APEC for tariff reduction in environmental goods is effective for environmental protection for two reasons. One is that demand increase by the domestic price decline in importing countries of environmental goods leads to environmental improvement through diffusion of the use of environmental goods together with strengthened environmental policies especially in the developing countries. ${ }^{11}$ The other is that supply increase in exporting countries leads to cost advantage under the production with increasing returns to scale. The environmental goods are generally thought to be the goods with increasing returns to scale, as they need large fixed costs such as costs for research and development.

Consequently, APEC should ensure the trade liberalization of environmental goods and continue efforts to add more environmental goods to the existing list. As the environmental goods in the APEC list are also considered in the plurilateral negotiations among the fourteen member countries in the WTO, APEC and the WTO may work together for worldwide reduction of tariffs and non-tariff barriers. Nowadays, we are aware of the necessity to go forward for environmental protection worldwide by adopting a new international order for mitigating the environmental risks. The adoption of the Paris Agreement of the 21st Session of the Conference of the Parties to the United Nations Framework Convention on Climate Change (COP21) in December 2015 is

\footnotetext{
${ }^{11}$ United Nations Environment Programme (2012) for details.
} 
regarded as crucial to achieve a new international framework to mitigate global warming, applicable to all of the 196 parties of different economic situations. The process for reaching the agreement showed us the importance of the reconciliation between developed and developing countries. ${ }^{12}$ From the point of view of the theme of trade and environment, a tighter international cooperation between developed and developing countries is definitely needed in order to advance trade liberalization for mitigation of environmental risks and to accelerate sustainable economic growth.

Received 4 January 2015, Revised 8 August 2015, Accepted 7 January 2016

\section{References}

Anderson, James and Eric van Wincoop. "Gravity with Gravitas: A Solution to the Border Puzzle." American Economic Review 93, no.1 (2003): 170-192.

Ando, Mitsuyo and Fukunari Kimura. "The Spatial Patterns of Production and Distribution Networks in East Asia." The Rise of Asia: Trade and Investment in Global Perspective, edited by Athukorala, Prema-chandra, 61-88. Oxton: Routledge, 2010.

Ando, Mitsuyo and Fukunari Kimura. "Production Linkage of Asia and Europe via Central and Eastern Europe.” Journal of Economic Integration 28, no.2 (2013): 204-240.

APEC (Asia-Pacific Economic Cooperation). "Vladivostok Declaration- Integrate to Grow, Innovate to Prosper." 2012. http://www.apec.org.

Athukorala, Prema-chandra. "Product Fragmentation and Trade Patterns in East Asia." Asian Economic Papers 4, no.3 (2006): 1-27.

Baier, Scott and Jeffrey H.Bergstrand. "The Growth of World Trade: Tariffs, Transport Costs, and Income Similarity." Journal of International Economics 53, no.1 (2001):1-27.

Balassa, Bela. "Trade Liberalisation and "Revealed" Comparative Advantage." The Manchester School 33, no.2 (1995): 99-123.

\footnotetext{
${ }^{12}$ Matsumura (2010) emphasizes the importance of the cooperation between developed and developing countries by pointing out the roles of the technological and financial aid.
} 
Baldwin, Richard and Daria Taglioni. "Gravity Chains: Estimating Bilateral Trade Flows when Parts and Components Trade is Important." NBER Working Paper Series 16672 , 2011.

Bergstrand, Jeffrey H. and Peter Egger. "A General Equilibrium Theory for Estimating Gravity Equations of Bilateral FDI, Final Goods Trade and Intermediate Goods Trade." In The Gravity Model in International Trade: Advances and Applications, edited by Peter A.G. van Bergeijk and Steven Brackman, 29-70. New York: Cambridge University Press, 2010.

Debaere, Peter. "Monopolistic Competition and Trade, Revisited: Testing the Model without Testing for Gravity." Journal of International Economics 66 (2005): 249-266.

Eurostat. "External Trade in High-tech Products." Luxembourg: Office for Official Publication of the European Communities, 1996.

Eurostat, Environmental Goods and Services Sector. office for official publication of the European Union, 2012. http://epp.eurostat.ec.europa.eu/statistics_explained/indes.php/ Environmental_goods_and_services_sector.

Feenstra, Robert C. "Advanced International Trade, Theory and Evidence." Princeton: Princeton University Press, 2004.

Frankel, Jeffrey H. "Regional Trading Blocs in the World Economic System." Washington, DC: Institute for International Economics, 1997.

Greenaway, David and Chris Milner. "Regionalism and Gravity." Scottish Journal of Political Economy 49, no.5 (2002): 574-585.

Ishida, Osamu. "Globalization and Trade Structure (In Japanese)." Tokyo: Bunshindo, 2011.

Jones,Ronald, W., Henryk.Kierzkowski and Chen Lurong. "What does Evidence Tell us about Fragmentation and Outsourcing?" International Review of Economics and Finance 14 (2005): 305-16.

Kimura, Fukunari "How Have Production Networks Changed Development Strategies in Asia?" Global Value Chains in a Changing World, edited by Deborah K. Elms and Patrick Low, 361-384. Geneva: World Trade Organization, Fung Global Institute and Nanyang Technological University, 2013. 
Kimura, Fukunari, Yuya Takahashi and Kazunobu Hayakawa. "Fragmentation and Parts and Components Trade: Comparison between East Asia and Europe." The North American Journal of Economics and Finance, 18, no.1 (2007): 23-40.

Krugman, Paul and Anthony Venables. "Integration, Specialization, and Adjustment." European Economic Review 40 (1996): 959-967.

Linnemann, Hans, “An Econometric Study of International Trade Flows." Amsterdam: North-Holland, 1966.

Matsumura, Atsuko. "Global Warming and International Trade: The Role of Economic Cooperation between Developed and Developing Countries for Sustainable Economic Growth." Forum on Public Policy: A Journal of the Oxford Round Table, Vol 2010, no. 3 (2010). http://forumonpublicpolicy.com/spring2010.vol2010/environment20103.html.

Matsumura, Atsuko. "Structure and Characteristics of Japanese Trade of Environmental Goods: Gravity Analysis Focusing on Intra-Industry Trade and FTA Effects. (In Japanese)" Boueki to Kanzei (Trade Journal): Japan Tariff Association 62, no.7, (2014): 62-77.

Möhlmann, L.Yan, Sjef Ederveen, Henri L.F.De Groot and Gert-Jan M.Linders. "Intangible Barriers to International Trade: a Sectoral Approach." The Gravity Model in International Trade, Advances and Applications, edited by Peter A.G. van Bergeijk and Steven Brackman, 224-254. New York: Cambridge University Press, 2010.

Organization for Economic Co-operafon and Development "Opening markets for Environmental Goods Services" policy Brief, september, 2005

Poyhonen, Pentti. "A Tentative Model for the Volume of Trade between Countries." Weltwirtschaftliches Archiv, 90, no.1 (1963): 93-100.

Rose, Andrew K., and Eric van Wincoop. "National Money as a Barrier to International Trade: The Real Case for Currency Union.” American Economic Review 90 (2001): 386390.

Tinbergen, Jan. "Shaping the World Economy: Suggestions for an International Economic Policy". New York: The Twentieth Century Fund, 1962.

United Nations Environment Programme. "Trade and Environment Briefings: Trade in Environmental Goods, Policy Brief 6." New York: United Nations, 2012. 
World Trade Organization. "Universe of Environmental Goods: Official HS Descriptions: Committee on Trade and Environment Special Session TN/TE/20." Geneva: WTO, 2011. 